\title{
Accuracy of sampling during mushroom cultivation for chemical analysis
}

J.J.P. Baars, P.M. Hendrickx \& A.S.M. Sonnenberg

WageningenUR, Plant Breeding

This study was carried out by Wageningen UR (University \& Research centre).

Wageningen UR is the collaboration of Wageningen University and the foundation Stichting Dienst Landbouwkundig Onderzoek.

Wageningen, December 2015

DOI: $10-18174 / 420929$

TKI T\&U: KV 1310-032

PPO/PRI report 2015-5 
Baars J.J.P., Hendrickx, P.M. \& Sonnenberg A.S.M., 2015. Accuracy of sampling in mushroom cultivation; . Wageningen, the foundation Stichting Dienst Landbouwkundig Onderzoek. Research Institute Praktijkonderzoek Plant \& Omgeving / Plant Research International, Wageningen UR (University \& Research centre), PPO/PRI report 2015-5.

Keywords: Agaricus bisporus, compost, biological efficiency

(C) 2015 Wageningen, Stichting Dienst Landbouwkundig Onderzoek, Research Institute Praktijkonderzoek Plant \& Omgeving/Plant Research International, P.O. Box 16, 6700 AA Wageningen, The Netherlands; T +31 (0)317 4807 00; www.wageningenur.nl/

Chamber of Commerce no. 09098104 te Arnhem

VAT NL no. 8065.11.618.B01

Stichting Dienst Landbouwkundig Onderzoek (DLO Foundation). All rights reserved. No part of this publication may be reproduced, stored in an automated database, or transmitted, in any form or by any means, whether electronically, mechanically, through photocopying, recording or otherwise, without the prior written consent of the DLO Foundation.

DLO is not liable for any adverse consequences resulting from the use of data from this publication.

PPO/PRI report 2015-5 


\section{Contents}

\section{Table of Contents}

$\begin{array}{ll}\text { Contents } & 3\end{array}$

Summary 5

$\begin{array}{lll}1 & \text { Introduction } & 7\end{array}$

$2 \quad$ Cultivation test. $\quad 8$

2.1 Cultivation history 8

$3 \quad$ Sampling compost $\quad 10$

3.1 Sampling dry matter and ash content of spawned compost. 10

3.2 Sampling dry matter and ash content of compost at casing. 11

3.3 Sampling dry matter and ash content of compost at the end of cultivation $\quad 13$

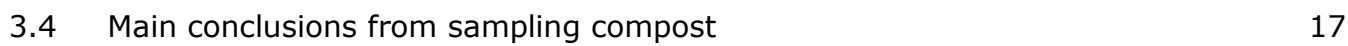

3.4.1 Increasing variability in the compost samples $\quad 17$

3.4.2 Increasing the accuracy with which dry matter and ash content as determined 18

$\begin{array}{llr}3.5 & \text { Recommendations } & 18\end{array}$

$4 \quad$ Sampling mushrooms $r$

4.1 Mushroom yield and quality in the different flushes $\quad 19$

4.2 Dry matter content of mushrooms 19

4.3 Comparison of methods used to calculate amount of dry matter that is produced.

5

Mass balances $\quad 22$

5.1 From spawning to casing $\quad 22$

5.2 From spawning till the end of cultivation 23

$\begin{array}{lll}5.3 & \text { Biological efficiency } & 24\end{array}$

6

Conclusions 



\section{Summary}

Experiments described in this report were performed to increase the accuracy of the analysis of the biological efficiency of Agaricus bisporus strains. Biological efficiency is a measure of the efficiency with which the mushroom strains use dry matter in the compost to produce mushrooms (expressed as dry matter produced).

In our experiments 3 mushroom strains were tested for biological efficiency. It aimed at finding the cause of the inaccuracy of determining biological efficiency. It focusses in the estimation of the amount of dry matter and ash in the compost and on the estimation of the amount of dry matter in the mushrooms.

The largest uncertainty was found in the amount of dry matter used from the compost. The methods used for sampling the compost to determine the mean value for dry matter content demonstrated a considerable variation between replicate samples taken from the compost. To lower variability in determination of dry matter and ash content, it was recommended to;

- Take an equally high number of replicate samples from all stages of cultivation (so 8 at spawning, 8 at casing, 8 at end of cultivation)

- Test the influence of homogenisation of samples of fresh compost (for instance, homogenisation by hand until homogeneous by eye in comparison to homogenising mechanically by using a cuttering machine which is operated at a standard speed for a standard time).

- $\quad$ Test for the optimal the amount of fresh compost in a sample to be analysed for dry matter content (for instance, 200, 400 and 600 gram)

- Test for the optimal amount of dried compost to be analysed for ash content (for instance, 10, 30 and 100 gram)

- Test if cultivation of the mushrooms on smaller portions of compost (for instance $8 \mathrm{~kg}$ in trays with $0.1 \mathrm{~m}^{2}$ growing surface or $4 \mathrm{~kg}$ in trays with $0.05 \mathrm{~m}^{2}$ growing surface), makes it easier to sample a large part of the compost used for cultivation. Next to this, more replicates will fit in a single growing room.

The uncertainty in the amount of dry matter produced in mushrooms is rather small. Using the dry matter content of mushrooms sampled at the peak days of a flush of mushrooms, provided a fairly accurate prediction of the actual amount of dry mass produced. In previous experiments it has been noted however, that some strains of mushrooms do not adhere to a production pattern in flushes, they produce mushrooms more or less continuously. To obtain a fair comparison for biological efficiency it would be advisable to harvest the mushrooms until no more mushrooms are produced.

Biological efficiency was calculated for the three strains tested and the least significant difference was found to be $5.7 \%$. We hope that future experiments on improvement of the methodology used, will lower this least significant difference. 


\section{Introduction}

In 2013, Baars \& Sonnenberg (2014) made a selection of wild isolates of Agaricus bisporus that differed widely with respect to efficiency with which dry matter in substrate was used in the production of mushrooms (i.e. biological efficiency). For this monokaryons were isolated by protoplasting and a variety of crosses was made among them. Successful crosses were grown on commercially available compost and their biological efficiency was tested. Among the various crosses, biological efficiency varied from 1.1 to $33.9 \%$. At $p=5 \%$, the least significant difference for comparisons between strains was $11.4 \%$. So, strains with a biological efficiency of $1.1 \%$ were not statistically significant different from strains with a biological efficiency of $11 \%$.

This large error in the determination is a problem if attempts are to be made for genomic mapping of the trait. If small differences in biological efficiency cannot reliably be discriminated, genomic mapping will be very hard to do.

Research described in this report is aimed at finding the cause of the inaccuracy of determining biological efficiency. It focusses in the estimation of the amount of dry matter and ash in the compost and on the estimation of the amount of dry matter in the mushrooms. For this we have grown Agaricus bisporus on commercially available compost in trays containing $16 \mathrm{~kg}$ of compost. During cultivation we sampled compost at spawning, at casing and after harvesting two (or three) flushes of mushrooms. Compost samples were analysed for dry matter content and ash content.

Mushrooms were harvested and sorted according to mushroom quality (Class 1 small, class 1 medium, class 2 small and class 2 medium). Our standard method for determining the yield of mushrooms was sampling the mushrooms at the days of peak production and analyse them for dry weight and ash content. In the experiment reported here we sampled all trays in this way. For comparison, a number of trays were analysed by taking all the mushrooms that were produced and analyse them for dry matter and ash content.

This report describes the results of the different sampling techniques. 


\section{Cultivation test.}

\section{$2.1 \quad$ Cultivation history}

The experiment was started on Tuesday, 26 May 2015 when phase 2 compost was obtained from CNC Grondstoffen. Compost was mixed and three samples were taken for determination of dry matter content and ash content. On Wednesday, 27 May 2015 the compost was spawned with either commercial strain A15 or the experimental strains MB-022 (=bisp15_p2 x Z8) and MB-031 (= bisp034_p1 x Z8). Spawned compost was filled in quantities of exactly $16 \mathrm{~kg}$ in trays with $0.2 \mathrm{~m}^{2}$ growing surface. For each strain 10 trays were filled.

The trays with spawned compost were covered with paper and incubated in a growing room at about $24^{\circ} \mathrm{C}$ (to maintain a compost temperature of $25^{\circ} \mathrm{C}$ ) and a relative humidity of $93-95 \%$.

At Thursday, 11 June 2015, after 15 days of spawn-run, for each strain 5 trays with colonised compost were sacrificed. From each tray all compost was mixed thoroughly until by eye an even compost mixture was obtained. From this mixture 8 separate samples of compost were taken and analysed for determination of dry matter content and ash content.

For each strain tested, the remaining 5 trays were covered with a casing soil (10 liter ( $7 \mathrm{~kg}$ ) CNC basismix nat per tray). No CAC-ing was applied. On Monday, 22 June 2015, after 11 days of casing soil colonisation, the casing layer was ruffled. On Thursday 25 June, after 14 days of casing soil colonisation, the trays were vented. First mushrooms were harvested from strain MB-022 on Wednesday, 1 July 2015. First mushrooms from strains A15 and MB-031, were harvested on Monday, 6 July 2015. The production profile of all strains is shown in Figure 1. Strain MB-022 was able to produce three flushes of mushrooms during the entire harvesting period, while strains A15 and MB-033 produced only two flushes.

On each harvesting day, mushrooms were graded into quality classes and weighed. Classes harvested were Class 1

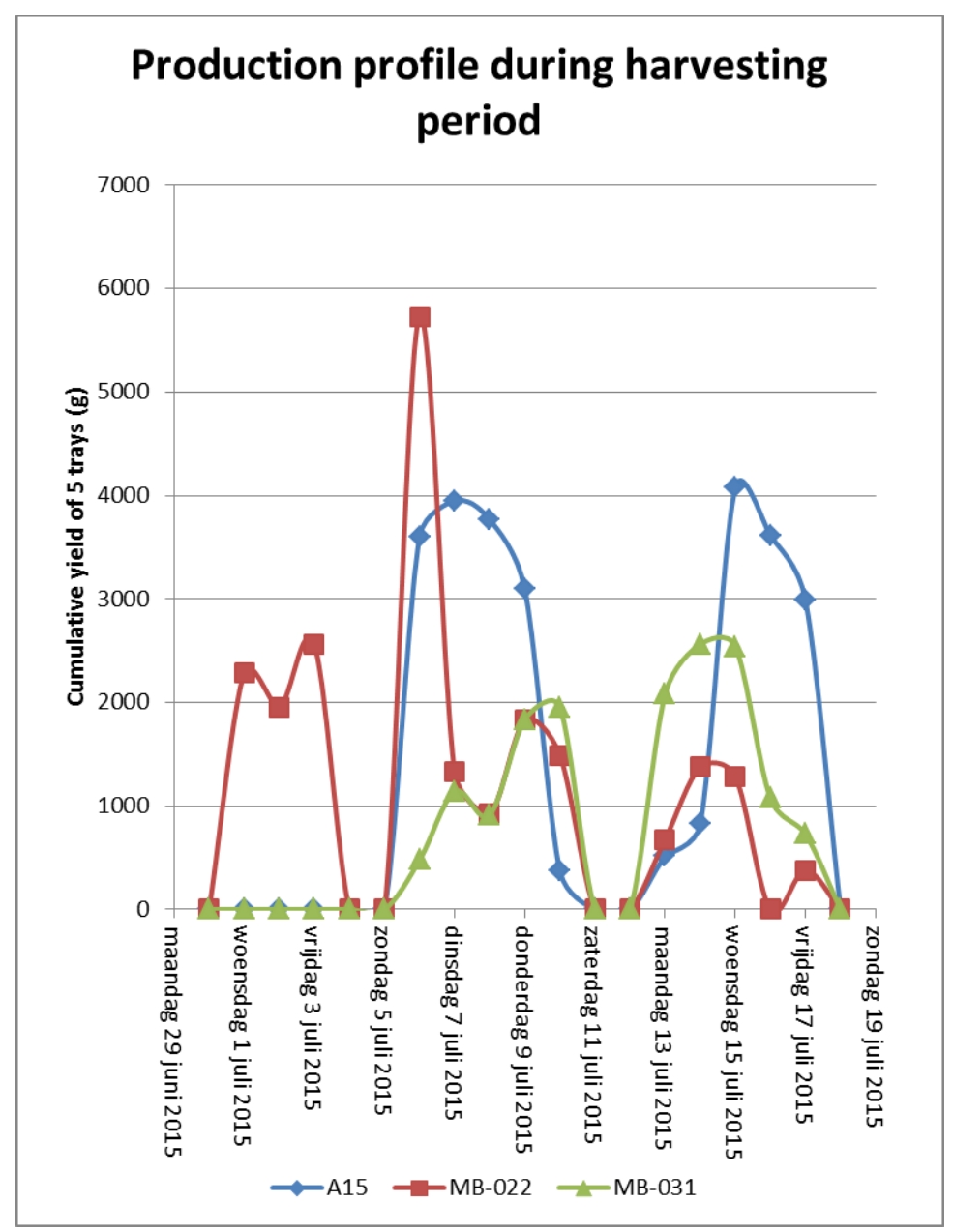

Figure 1. Production profile of strains A15, MB-022 and MB-033 during the experiment. small, Class 1 middle, Class 2 small and Class 2 middle. For all mushrooms produced, fresh weighed was determined. For 3 out of the 5 trays per strain, all mushrooms were dried to determine dry matter content. For the remaining 2 out of 5 trays per strain, dry matter content was determined on a sample of mushrooms taken on a peak day of production in each flush.

On Friday, 17 July 2015, composts were sampled again. From each tray all compost was mixed thoroughly until by eye, an even compost mixture was obtained. From this mixture 8 separate 
samples of compost were taken and analysed for determination of dry matter content and ash content. After this the growing room was steamed. 


\section{Sampling compost}

\subsection{Sampling dry matter and ash content of spawned compost.}

At the start of the cultivation experiment, phase 2 compost was thoroughly mixed and three random samples were taken for determination of dry matter and ash content. For determination of dry matter content, samples of $600-700$ gram of compost were first dried at $70^{\circ} \mathrm{C}$. After this they were dried at $105^{\circ} \mathrm{C}$ until constant weight (usually 2-3 days). For determination of ash content, $11-13$ gram of milled compost which was dried at $105^{\circ} \mathrm{C}$ was heated at $550^{\circ} \mathrm{C}$ in a muffle furnace for 4 hours.

An overview of the experimental values of three subsamples of spawned compost are shown in Table 1. The mean value for dry matter content is $339.8 \mathrm{~g} / \mathrm{kg}$. The mean value for ash content was 375.7 $\mathrm{g} / \mathrm{kg}$. To appreciate the numbers in Table 1 to their full value we first need to explain standard deviation and standard error of the mean (SEM). The standard deviation (St dev) quantifies variability or scatter in the measurements, and it is expressed in the same units as the data. If the data are sampled from a Gaussian distribution, then you expect $68 \%$ of the values to lie within one SD of the mean and $95 \%$ to lie within two SD of the mean. The standard error of the mean (SEM) quantifies the precision of the mean. It is a measure of how far your sample mean is likely to be from the true population mean. It is expressed in the same units as the data. The $95 \%$ confidence interval extends approximately two SEMs from the mean in each direction.

To estimate the accuracy with which the dry matter content was determined, the $95 \%$ confidence interval was calculated. The confidence interval of a mean is centred on the sample mean, and extends symmetrically in both directions. That distance equals the standard error of the mean times a constant from the t distribution. The value of that constant depends only on sample size $(\mathrm{N})$ and is 4.303 for $\mathrm{N}=3$. From this we can calculate that the dry matter content of the spawned compost lies with $95 \%$ confidence between 331.7 and $348.0 \mathrm{~g} / \mathrm{kg}$ fresh weight. The ash content of the spawned compost lies between 338.2 and $413 \mathrm{~g} / \mathrm{kg}$ dry matter.

Table 1. Dry matter content and ash content of the phase 2 compost used at the start of the cultivation experiment.

\begin{tabular}{|lcc|}
\hline Sample & $\begin{array}{c}\text { Dry matter content } \\
(\mathrm{g} / \mathrm{kg} \text { FM) }\end{array}$ & $\begin{array}{c}\text { Ash content }(\mathrm{g} / \mathrm{kg} \\
\text { DM) }\end{array}$ \\
\hline Subsample 1 & 342.6 & 392.4 \\
\hline Subsample 2 & 340.8 & 363.3 \\
\hline Subsample 3 & 336.2 & 371.3 \\
\hline & & 375.7 \\
\hline Average & 339.8 & 15.0 \\
\hline Standard deviation & 3.3 & $4.0 \%$ \\
\hline St. dev. as \% of the mean & $1.0 \%$ & 8.7 \\
\hline Standard error of the mean & 1.9 & 338.2 \\
\hline 95\% confidence lower boundary & 331.7 & 413.1 \\
\hline 95\% confidence upper boundary & 348.0 & \\
\hline
\end{tabular}




\subsection{Sampling dry matter and ash content of compost at casing.}

At Thursday, 11 June 2015, after 15 days of spawn-run, for each strain 5 trays with colonised compost were sacrificed. From each tray all compost was mixed thoroughly until by eye an even compost mixture was obtained. From this mixture 8 separate samples of compost were taken and analysed for determination of dry matter content and ash content. For determination of dry matter content, on

Table 2. Dry matter content of the trays of compost sacrificed at casing. Results shown are an average of 8 subsamples per tray.

\begin{tabular}{|c|c|c|c|c|c|c|c|}
\hline Tray & Strain & $\begin{array}{l}\text { Mean DM } \\
\text { (g/kg FW) }\end{array}$ & $\begin{array}{l}\text { St. Dev. } \\
\text { (g/kg FW) }\end{array}$ & $\begin{array}{c}\text { St. dev. } \\
(\%)\end{array}$ & SEM & $\begin{array}{c}\text { Lower } \\
95 \% \\
\text { confidence } \\
\text { level }\end{array}$ & $\begin{array}{c}\text { Upper } \\
95 \% \\
\text { confidence } \\
\text { level }\end{array}$ \\
\hline 1 & MB-031 & 356.9 & 4.9 & $1.4 \%$ & 1.7 & 353.5 & 360.4 \\
\hline 2 & MB-031 & 353.2 & 4.2 & $1.2 \%$ & 1.5 & 350.2 & 356.2 \\
\hline 3 & MB-022 & 349.9 & 4.1 & $1.2 \%$ & 1.4 & 347.0 & 352.8 \\
\hline 4 & A15 & 341.0 & 8.3 & $2.4 \%$ & 2.9 & 335.1 & 346.8 \\
\hline 5 & A15 & 345.0 & 6.9 & $2.0 \%$ & 2.4 & 340.1 & 349.9 \\
\hline 6 & MB-031 & 347.0 & 4.8 & $1.4 \%$ & 1.7 & 343.6 & 350.3 \\
\hline 7 & A15 & 348.8 & 2.7 & $0.8 \%$ & 1.0 & 346.9 & 350.7 \\
\hline 8 & A15 & 356.7 & 3.3 & $0.9 \%$ & 1.2 & 354.3 & 359.0 \\
\hline 9 & MB-022 & 356.7 & 6.8 & $1.9 \%$ & 2.4 & 351.9 & 361.4 \\
\hline 10 & MB-022 & 346.0 & 2.1 & $0.6 \%$ & 0.7 & 344.5 & 347.5 \\
\hline 11 & MB-022 & 347.8 & 3.0 & $0.9 \%$ & 1.1 & 345.7 & 349.9 \\
\hline 12 & MB-031 & 353.8 & 2.5 & $0.7 \%$ & 0.9 & 352.0 & 355.5 \\
\hline 13 & MB-031 & 345.0 & 5.1 & $1.5 \%$ & 1.8 & 341.4 & 348.5 \\
\hline 14 & MB-022 & 340.7 & 2.2 & $0.6 \%$ & 0.8 & 339.2 & 342.3 \\
\hline 15 & A15 & 345.4 & 2.4 & $0.7 \%$ & 0.8 & 343.8 & 347.1 \\
\hline
\end{tabular}

Table 3. Ash content of the trays of compost sacrificed at casing. Results shown are an average of 8 subsamples per tray.

\begin{tabular}{|llcccccc|} 
Tray & Strain & $\begin{array}{c}\text { Mean } \\
\text { Ash } \\
\text { content } \\
(\mathbf{g} / \mathbf{k g ~ D M})\end{array}$ & $\begin{array}{c}\text { St. Dev. } \\
(\mathbf{g} / \mathbf{k g} \text { DM })\end{array}$ & $\begin{array}{c}\text { St. dev. } \\
\%\end{array}$ & SEM & $\begin{array}{c}\text { Lower } \\
95 \% \\
\text { confidence } \\
\text { level }\end{array}$ & $\begin{array}{c}\text { Upper } \\
95 \% \\
\text { confidence } \\
\text { level }\end{array}$ \\
\hline $\mathbf{1}$ & MB-031 & 359.9 & 24.1 & $6.7 \%$ & 8.5 & 342.9 & 376.9 \\
\hline $\mathbf{2}$ & MB-031 & 349.9 & 17.9 & $5.1 \%$ & 6.3 & 337.3 & 362.6 \\
\hline $\mathbf{3}$ & MB-022 & 354.0 & 20.2 & $5.7 \%$ & 7.2 & 339.7 & 368.3 \\
\hline $\mathbf{4}$ & A15 & 358.4 & 24.3 & $6.8 \%$ & 8.6 & 341.2 & 375.6 \\
\hline $\mathbf{5}$ & A15 & 341.8 & 22.2 & $6.5 \%$ & 7.9 & 326.1 & 357.5 \\
\hline $\mathbf{6}$ & MB-031 & 345.5 & 14.0 & $4.1 \%$ & 5.0 & 335.5 & 355.4 \\
\hline $\mathbf{8}$ & A15 & 343.7 & 15.0 & $4.4 \%$ & 5.3 & 333.1 & 354.3 \\
\hline $\mathbf{9}$ & MB-022 & 361.3 & 13.9 & $3.8 \%$ & 4.9 & 351.5 & 371.1 \\
\hline $\mathbf{1 0}$ & MB-022 & 345.4 & 38.3 & $10.1 \%$ & 13.5 & 353.4 & 407.5 \\
\hline $\mathbf{1 1}$ & MB-022 & 353.2 & 7.8 & $3.9 \%$ & 4.8 & 335.7 & 354.9 \\
\hline $\mathbf{1 2}$ & MB-031 & 347.4 & 15.2 & $4.4 \%$ & 2.7 & 347.7 & 358.7 \\
\hline $\mathbf{1 3}$ & MB-031 & 325.2 & 22.8 & $7.0 \%$ & 8.0 & 309.1 & 341.3 \\
\hline $\mathbf{1 4}$ & MB-022 & 335.4 & 10.2 & $3.1 \%$ & 3.6 & 328.2 & 342.6 \\
\hline $\mathbf{1 5}$ & A15 & 333.2 & 29.5 & $8.9 \%$ & 10.4 & 312.3 & 354.1 \\
\hline
\end{tabular}

different mushroom strains grown in an ANOVA, no statistically significant differences are found. average samples of $150-284$ gram of compost (on average $209 \mathrm{~g}$ ) were first dried at $70^{\circ} \mathrm{C}$. After this they were dried at $105^{\circ} \mathrm{C}$ until constant weight (usually 2-3 days). For determination of ash content, 
10 - 16 gram (on average $13 \mathrm{~g}$ ) of compost which was dried at $105^{\circ} \mathrm{C}$ was heated at $550^{\circ} \mathrm{C}$ in a muffle furnace for 4 hours. Results for the dry matter and ash content of the different trays are shown in Tables 2 and 3, respectively. When comparing the dry matter and ash content of the compost for the Compost colonised by strain A15 has a dry matter content of $347 \mathrm{~g} / \mathrm{kg} \mathrm{FW}$ and an ash content of 348 $\mathrm{g} / \mathrm{kg}$ DM. Compost colonised by strain MB-022 has a dry matter content of $348 \mathrm{~g} / \mathrm{kg} \mathrm{FW}$ and an ash content of $354 \mathrm{~g} / \mathrm{kg}$ DM. Compost colonised by strain MB-031 has a dry matter content of $351 \mathrm{~g} / \mathrm{kg}$ FW and an ash content of $346 \mathrm{~g} / \mathrm{kg}$ DM.

When sampling compost for determination of dry weight and ash content there is always variation between the subsamples taken. The level of variation is expressed as the standard deviation. The
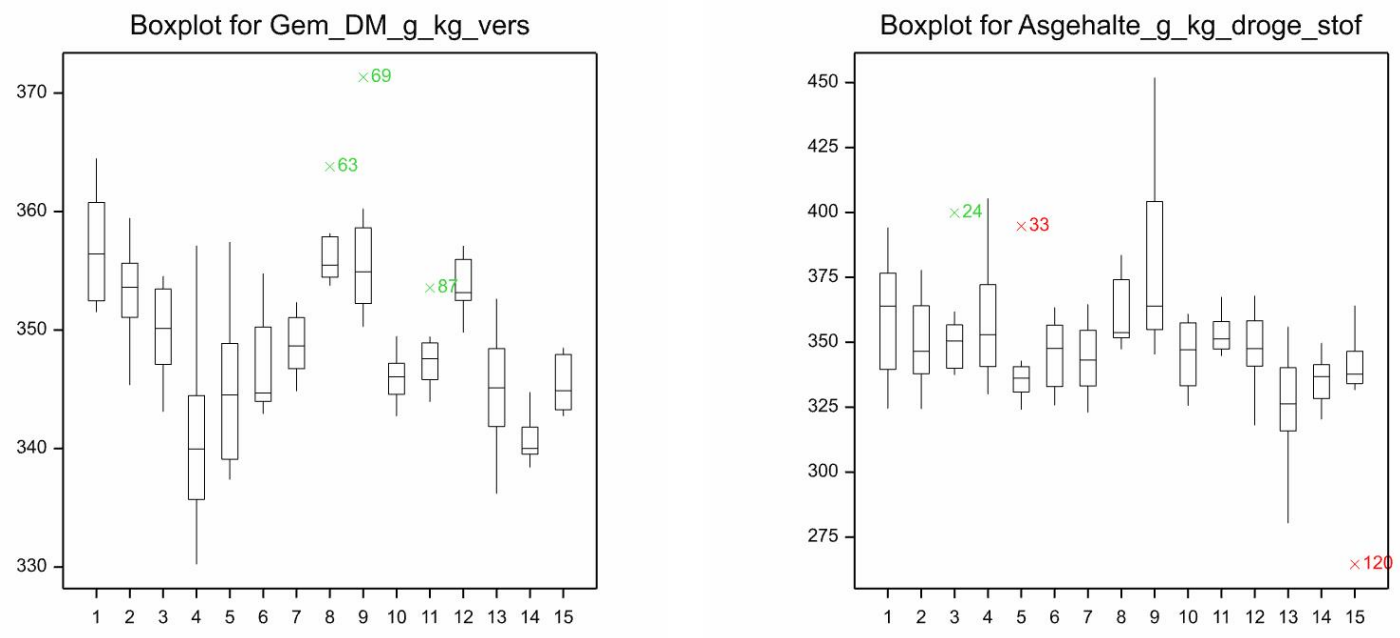

Figure 2. Box plots of the mean values for dry matter and ash content of composts in the 15 different trays at casing

accuracy with which we were able to determine the dry weight and ash content of the compost can be deduced from the standard error of the mean.

Figure 2 shows box plots for the values of dry matter and ash content and the level of variation in the values. The boxes span the interquartile range of the values in the variate, so that the middle $50 \%$ of the data lie within the box, with a line indicating the median. Whiskers extend beyond the ends of the box as far as the minimum and maximum values. Figure 2 demonstrates that there is quite some tray to tray variation within the dataset. While the values for dry matter content vary between 330 and $370 \mathrm{~g} / \mathrm{kg}$, the values of the ash content vary between 275 and $450 \mathrm{~g} / \mathrm{kg}$.

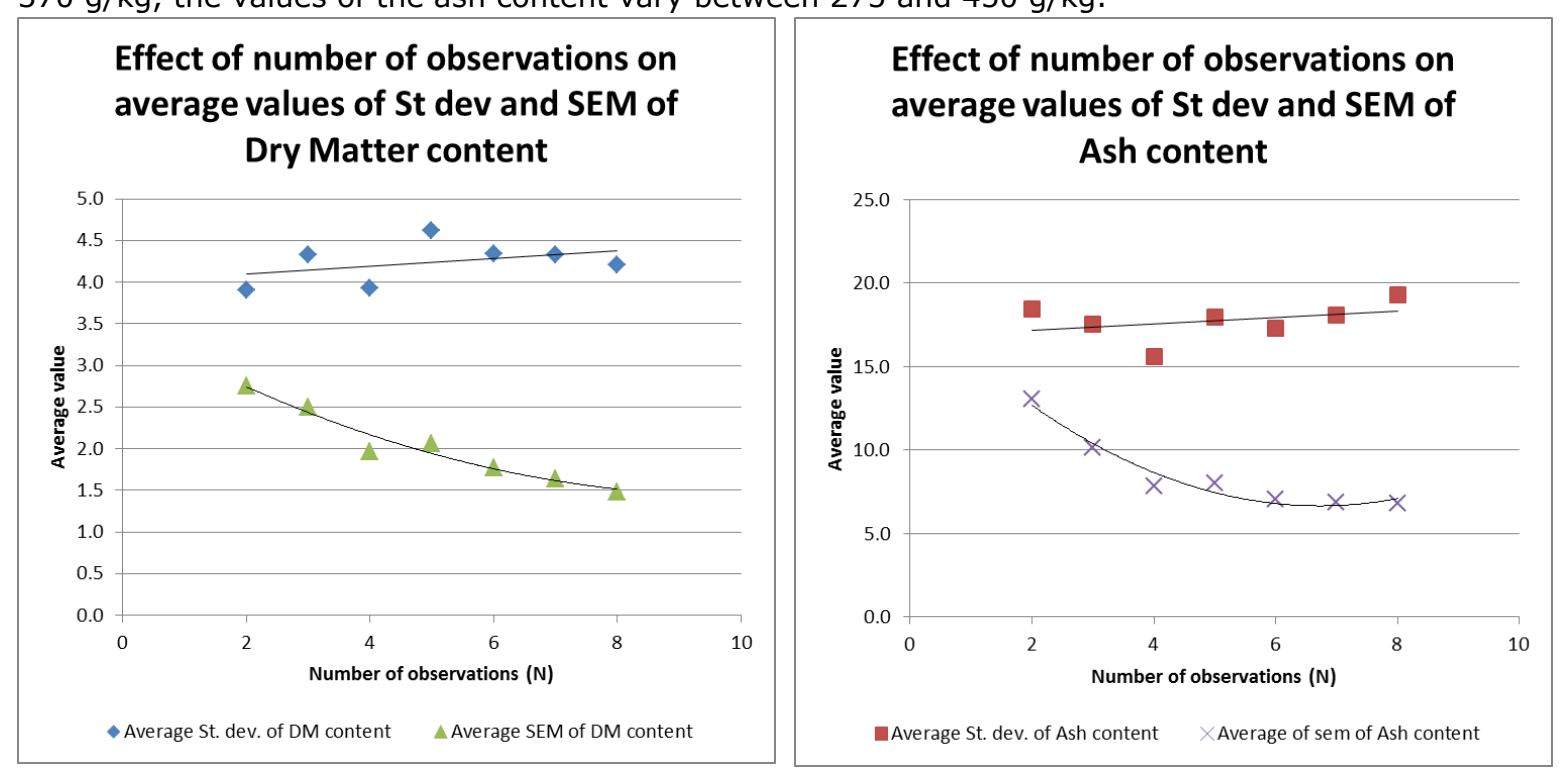

Figure 3. Relation between the average value for the standard deviation and SEM of dry matter content and ash content at casing as a function of the number of observations. 
Figure 3 shows to what extent the standard error of the mean (SEM) depends on the number of observations (N). SEM quantifies the precision of the mean. It is a measure of how far your sample mean is likely to be from the true population mean. For each tray we calculated St. dev. and SEM at different numbers of observations. The individual observations are listed in Annex 1 . So for $\mathrm{N}=2$ we used the first 2 out of the 8 observations listed for each individual tray, for $N=3$ we used the first 3 observations out of 8 , and so on. As there were no statistically significant differences, we calculated this for all 15 trays in the experiment. As can be seen, the standard deviation for dry matter and ash content does not change with an increasing number of observations. The SEM becomes lower as the number of observations increases. As SEM becomes lower, the estimate of dry matter and ash content becomes more accurate.

\subsection{Sampling dry matter and ash content of compost at the end of cultivation}

Friday, 17 July 2015, at the end of the cultivation trial, for each strain 5 trays with colonised compost were sacrificed. From each tray all compost was mixed thoroughly until by eye, an even compost mixture was obtained. From this mixture 8 separate samples of compost were taken and analysed for determination of dry matter content and ash content. For determination of dry matter content, on average samples of $260-464$ gram of compost (on average $242 \mathrm{~g}$ ) were first dried at $70^{\circ} \mathrm{C}$. After this they were dried at $105^{\circ} \mathrm{C}$ until constant weight (usually 2-3 days). For determination of ash content, 15 - 24 gram (on average $20 \mathrm{~g}$ ) of compost which was dried at $105^{\circ} \mathrm{C}$, was heated at $550^{\circ} \mathrm{C}$ in a muffle furnace for 4 hours.

At the end of the cultivation trial, ANOVA showed statistically significant differences in dry matter content of the compost colonised by different mushroom strains (Table 4). No significant differences were found with respect to ash content.

Table 4. Overview of dry matter and ash content of compost colonised by the different mushroom strains.

\begin{tabular}{|lcccc|}
\hline Strain & $\begin{array}{c}\text { DM content } \\
(\mathbf{g} / \mathbf{k g ~ F W})\end{array}$ & I.s.d. $=10.77$ & $\begin{array}{c}\text { Ash content } \\
(\mathbf{g} / \mathbf{k g ~ D M})\end{array}$ & I.s.d. $=13.98$ \\
\hline MB-031 & 341.6 & $\mathrm{a}$ & 448.2 & $\mathrm{a}$ \\
\hline A15 & 361.3 & $\mathrm{~b}$ & 449.0 & $\mathrm{a}$ \\
\hline MB-022 & 369.6 & $\mathrm{~b}$ & 455.1 & $\mathrm{a}$ \\
\hline
\end{tabular}

Details on the values obtained in the different trays with respect to the determination of the dry matter are given in Table 5. When comparing the standard deviation as a percentage of the averages, it can be seen that the variation increases as cultivation progresses. At spawning the dry matter content of the compost was $340 \mathrm{~g} / \mathrm{kg}$ FW with a standard deviation of $1 \%$. At casing the dry matter content of the composts ranged, regardless of the mushroom strain, from 341 to $357 \mathrm{~g} / \mathrm{kg}$ FW with standard deviations varying between 0.6 and $2.4 \%$. At the end of cultivation, the dry weight contents of the composts differ widely with the mushroom strains that colonised them and standard deviations vary from 1.7 to $3.9 \%$.

The accuracy with which dry matter content of the composts has been determined (SEM) cannot be compared directly. At spawning only 3 observations were made on dry matter content, while at casing and at the end of cultivation, 8 observations are available per tray. However, when comparing the SEM values at casing with the SEM values at the end of cultivation, it can be seen that accuracy has decreased. The SEM values increased from values in the range of 0.7 to 2.9 at casing to values in the range of 2.0 to 4.7 at the end of cultivation.

Details on the values for ash content in the different trays at the end of cultivation are shown in Table 6. There are no statistically significant differences in ash content between the composts colonised by the different mushroom strains. Also for the ash content it can be seen that variation increases during cultivation by comparing the standard deviations. At spawning the standard deviation of the ash 
Table 5. Dry matter content of the trays of compost sacrificed at the end of cultivation. Results shown are an average of 8 subsamples per tray.

\begin{tabular}{|c|c|c|c|c|c|c|c|}
\hline Strain & Tray & $\begin{array}{l}\text { Mean DM } \\
(\mathrm{g} / \mathrm{kg} \mathrm{FW})\end{array}$ & $\begin{array}{c}\text { St. Dev } \\
(\mathrm{g} / \mathrm{kg} \mathrm{FW})\end{array}$ & $\begin{array}{l}\text { St dev. } \\
(\%)\end{array}$ & SEM & $\begin{array}{c}\text { Lower } \\
95 \% \\
\text { confidence } \\
\text { level }\end{array}$ & $\begin{array}{c}\text { Upper } \\
95 \% \\
\text { confidence } \\
\text { level }\end{array}$ \\
\hline \multirow[t]{6}{*}{ A15 } & Average & 361.3 & 9.6 & $2.7 \%$ & 3.4 & 353.6 & 369.1 \\
\hline & 4 & 364.5 & 6.3 & $1.7 \%$ & 2.2 & 359.3 & 369.6 \\
\hline & 5 & 358.7 & 8.6 & $2.4 \%$ & 3.0 & 351.7 & 365.7 \\
\hline & 7 & 367.3 & 10.9 & $3.0 \%$ & 3.8 & 358.5 & 376.2 \\
\hline & 8 & 363.8 & 8.3 & $2.3 \%$ & 2.9 & 357.0 & 370.6 \\
\hline & 15 & 352.4 & 7.2 & $2.0 \%$ & 2.5 & 346.6 & 358.3 \\
\hline \multirow[t]{6}{*}{ MB-022 } & Average & 369.6 & 13.4 & $3.6 \%$ & 4.7 & 358.7 & 380.5 \\
\hline & 3 & 373.6 & 7.8 & $2.1 \%$ & 2.7 & 367.3 & 379.9 \\
\hline & 9 & 373.2 & 10.7 & $2.9 \%$ & 3.8 & 364.5 & 381.9 \\
\hline & 10 & 384.4 & 10.7 & $2.8 \%$ & 3.8 & 375.7 & 393.1 \\
\hline & 11 & 352.6 & 5.9 & $1.7 \%$ & 2.1 & 347.8 & 357.4 \\
\hline & 14 & 364.1 & 4.9 & $1.3 \%$ & 1.7 & 360.1 & 368.0 \\
\hline \multirow[t]{6}{*}{ MB-031 } & Average & 341.6 & 8.1 & $2.4 \%$ & 2.9 & 334.9 & 348.2 \\
\hline & 1 & 340.4 & 6.9 & $2.0 \%$ & 2.4 & 334.8 & 346.0 \\
\hline & 2 & 337.7 & 5.7 & $1.7 \%$ & 2.0 & 333.1 & 342.3 \\
\hline & 6 & 344.2 & 13.3 & $3.9 \%$ & 4.7 & 333.3 & 355.0 \\
\hline & 12 & 343.4 & 6.7 & $1.9 \%$ & 2.4 & 338.0 & 348.9 \\
\hline & 13 & 342.1 & 6.0 & $1.7 \%$ & 2.1 & 337.2 & 346.9 \\
\hline
\end{tabular}

Table 6. Ash content of the trays of compost sacrificed at the end of cultivation. Results shown are an average of 8 subsamples per tray.

\begin{tabular}{|c|c|c|c|c|c|c|c|}
\hline Strain & Tray & $\begin{array}{c}\text { Mean } \\
\text { Ash } \\
\text { Content } \\
\text { (g/kg DM) }\end{array}$ & $\begin{array}{c}\text { St. Dev } \\
(\mathrm{g} / \mathrm{kg} \mathrm{DM})\end{array}$ & $\begin{array}{c}\text { St dev } \\
(\%)\end{array}$ & SEM & $\begin{array}{c}\text { Lower } \\
95 \% \\
\text { confidence } \\
\text { level }\end{array}$ & $\begin{array}{c}\text { Upper } \\
95 \% \\
\text { confidence } \\
\text { level }\end{array}$ \\
\hline \multirow[t]{6}{*}{ A15 } & Average & 449.0 & 15.0 & $3.3 \%$ & 5.3 & 436.8 & 461.2 \\
\hline & 4 & 467.6 & 15.6 & $3.3 \%$ & 5.5 & 454.9 & 480.3 \\
\hline & 5 & 440.4 & 8.3 & $1.9 \%$ & 2.9 & 433.7 & 447.2 \\
\hline & 7 & 444.9 & 10.6 & $2.4 \%$ & 3.8 & 436.2 & 453.5 \\
\hline & 8 & 437.4 & 8.7 & $2.0 \%$ & 3.1 & 430.3 & 444.5 \\
\hline & 15 & 454.9 & 7.7 & $1.7 \%$ & 2.7 & 448.7 & 461.2 \\
\hline \multirow[t]{6}{*}{ MB-022 } & Average & 455.1 & 12.8 & $2.8 \%$ & 4.5 & 444.7 & 465.5 \\
\hline & 3 & 460.0 & 13.5 & $2.9 \%$ & 4.8 & 449.0 & 470.9 \\
\hline & 9 & 453.5 & 7.6 & $1.7 \%$ & 2.7 & 447.3 & 459.7 \\
\hline & 10 & 454.2 & 13.9 & $3.1 \%$ & 4.9 & 442.9 & 465.6 \\
\hline & 11 & 462.5 & 13.4 & $2.9 \%$ & 4.7 & 451.6 & 473.4 \\
\hline & 14 & 445.2 & 9.4 & $2.1 \%$ & 3.3 & 437.5 & 452.8 \\
\hline \multirow[t]{6}{*}{ MB-031 } & Average & 448.2 & 15.7 & $3.5 \%$ & 5.5 & 435.5 & 461.0 \\
\hline & 1 & 460.8 & 15.6 & $3.4 \%$ & 5.5 & 448.2 & 473.5 \\
\hline & 2 & 442.7 & 12.2 & $2.7 \%$ & 4.3 & 432.9 & 452.6 \\
\hline & 6 & 433.7 & 12.4 & $2.9 \%$ & 4.4 & 423.7 & 443.8 \\
\hline & 12 & 455.3 & 15.7 & $3.4 \%$ & 5.5 & 442.5 & 468.0 \\
\hline & 13 & 448.6 & 8.3 & $1.9 \%$ & 2.9 & 441.9 & 455.4 \\
\hline
\end{tabular}



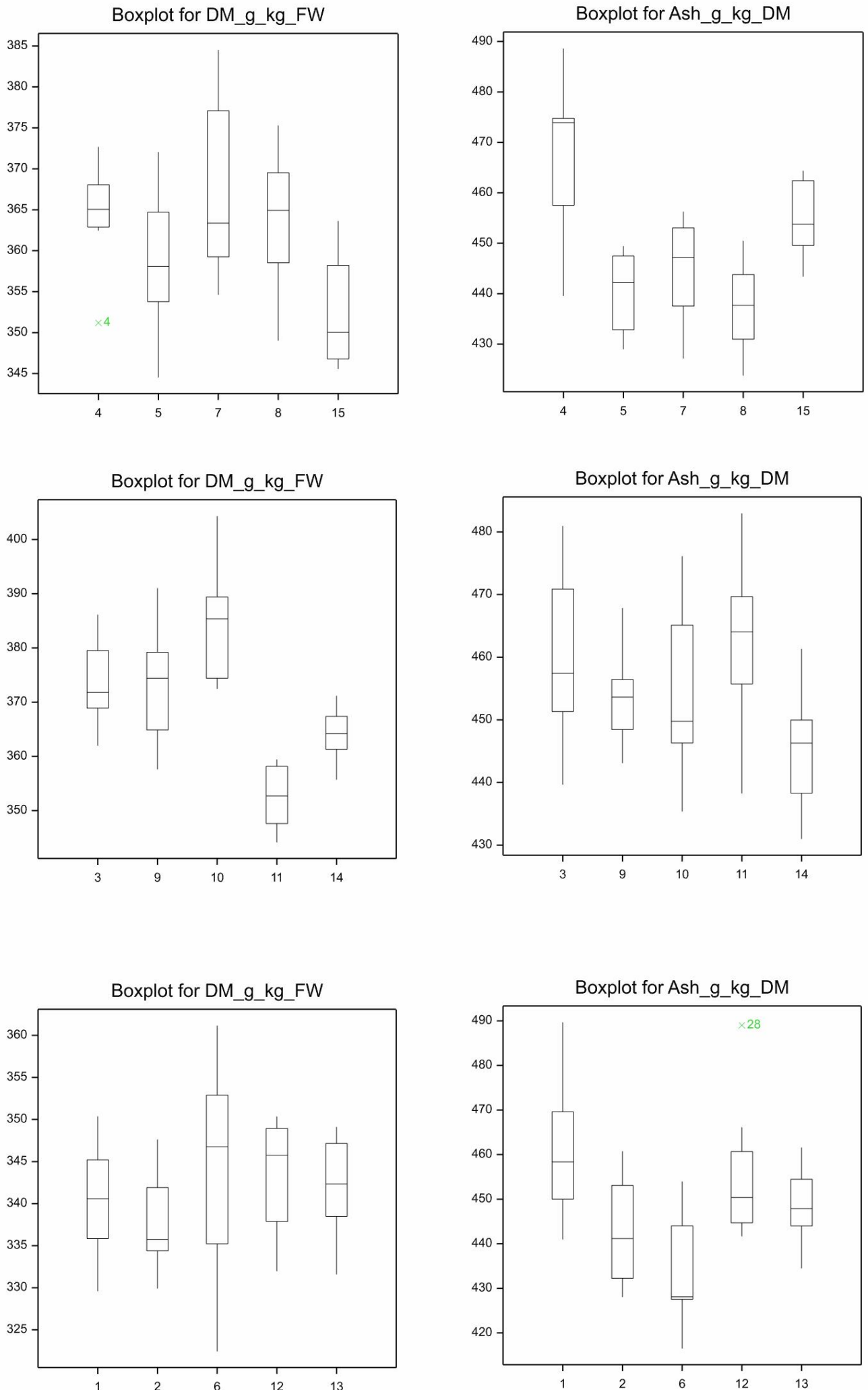

Figure 4. Box plots of the mean values for dry matter and ash content of composts in the 15 different trays at the end of cultivation. The top two graphs represent variation in dry matter content and ash content in different trays of compost containing strain A15. The middle two graphs represent variation in dry matter content and ash content in different trays of compost containing strain MB-022. The bottom two graphs represent variation in dry matter content and ash content in different trays of compost containing strain MB-031. 
content of the compost was $4 \%$ (on an ash content of $376 \mathrm{~g} / \mathrm{kg} \mathrm{DM}$ ). At casing the standard deviation had increased to values between 2.7 and $13.5 \%$ (on ash contents between 333 and $380 \mathrm{~g} / \mathrm{kg} \mathrm{DM}$ ).

Strangely enough, at the end of cropping the standard deviation on the ash content was reduced again to values between 1.7 and 3.5\%. At different moment during the cultivation experiment, the dry matter content was determined on different amounts of fresh compost. Also ash content was determined on different amounts of dry matter. Perhaps a part of the variation in the standard deviation can be attributed to these differences.

Figure 4 shows box plots for the values of dry matter and ash content and the level of variation in the values. As there are significant differences in the dry matter and ash contents of the composts containing different mushroom strains, graphs are showing the values for the different trays in which a strain has grown. The boxes span the interquartile range of the values in the variate, so that the middle $50 \%$ of the data lie within the box, with a line indicating the median. Whiskers extend beyond the ends of the box as far as the minimum and maximum values. As can be seen, there is quite some variation between the samples taken from a tray. Next to this there is quite some variation between trays that have been colonised by the same mushroom strain.

Figure 5 shows to what extent the standard error of the mean (SEM) depends on the number of observations $(\mathrm{N})$. SEM quantifies the precision of the mean. It is a measure of how far your sample mean is likely to be from the true population mean. For each tray we calculated St. dev. and SEM at different numbers of observations. The individual observations are listed in Annex 1 . So for $\mathrm{N}=2$ we used the first 2 out of the 8 observations listed for each individual tray, for $\mathrm{N}=3$ we used the first 3
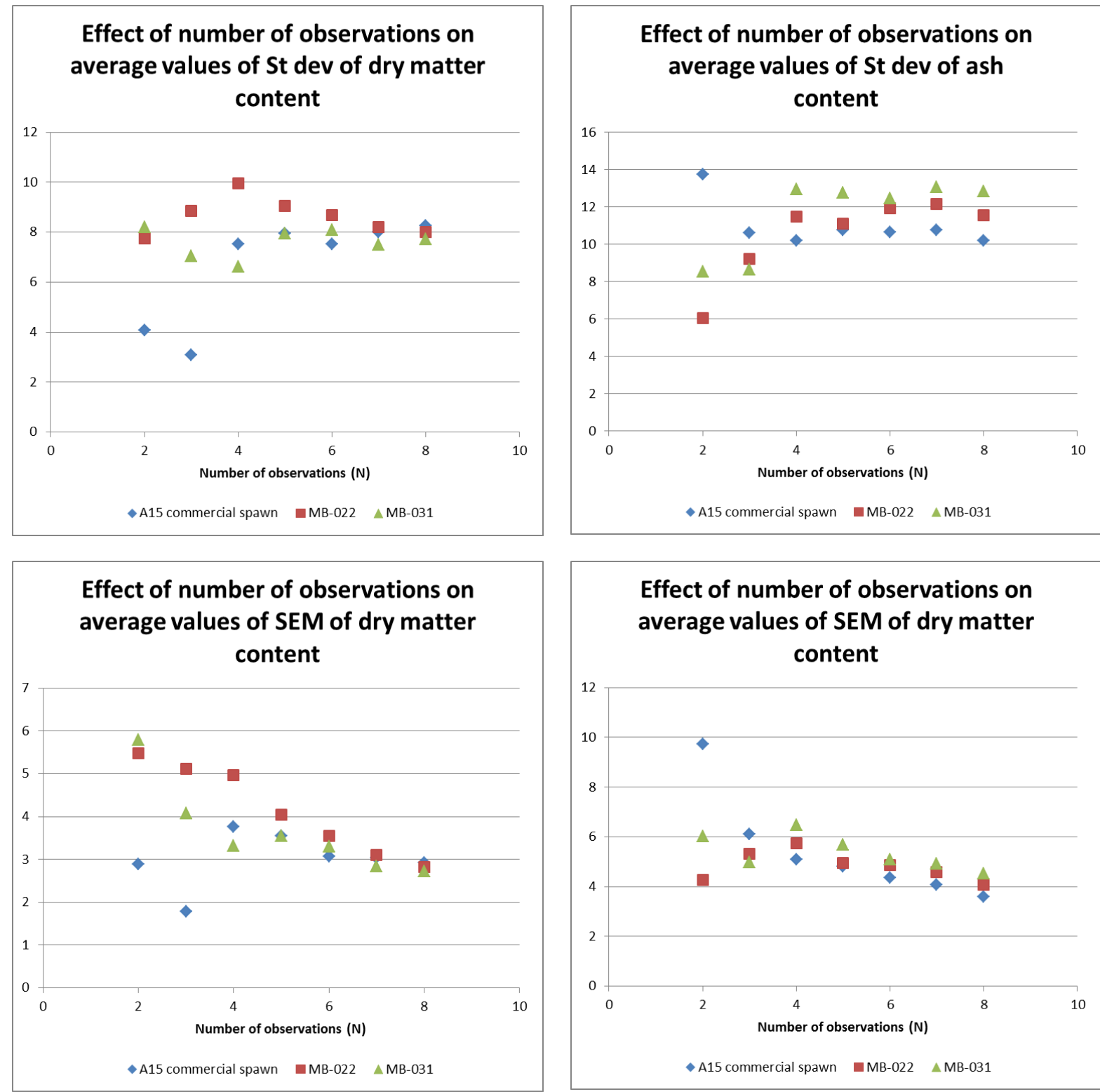

Figure 5. Relation between the average value for the standard deviation and SEM of dry matter content and ash content at the end of cultivation as a function of the number of observations. 
observations out of 8 , and so on. As there are statistically significant differences between strains, we represent the values for each strain separately. As can be seen, the standard deviation for dry matter and ash content changes with an increasing number of observations. Only at more than 5

observations, the standard deviation for dry matter content starts to stabilise at a value of $8 \%$. The same trend can be seen for the ash content. Standard deviation for the ash content stabilises at 10$13 \%$ starting from 4 or more observations.

The SEM becomes lower as the number of observations increases. As SEM becomes lower, the estimate of dry matter and ash content becomes more accurate.

\subsection{Main conclusions from sampling compost}

\subsubsection{Increasing variability in the compost samples}

In summary, compost was sampled at spawning, at casing and at the end of cultivation and analysed for dry matter and ash content. At spawning, 3 compost samples of $600-700$ gram of fresh compost were analysed for dry matter content, at casing, 8 compost samples of $150-284$ gram of compost were analysed for dry matter content for each tray and at the end of cultivation, 8 compost samples of 260 - 464 gram of compost were analysed for dry matter content for each tray.

When comparing standard deviation of dry matter (expressed as a percentage of the mean value for dry matter content) during the course of cultivation, the average value raises from $1 \%$ at spawning to $4-5 \%$ at casing and about $8 \%$ at the end of cultivation. This increase in variability in the results is partly caused by an increase of heterogeneity within the trays of compost.

The same happens to a larger extent for the ash content. At spawning 3 samples of , $11-13$ gram of dried and milled compost were analysed for ash content. At casing, for each tray, 8 samples of $10-$ 16 gram of dried compost were analysed for ash content. At the end of cultivation, for each tray, 8 samples of 15 - 24 gram of dried compost were analysed for ash content.

When comparing standard deviation (again expressed as a percentage of the mean value for ash content) during the course of cultivation, values raise from $4 \%$ at spawning to $15-20 \%$ at casing and 8 to $15 \%$ at the end of cultivation.

Compared to the standard deviation of the dry matter content, the standard deviation for the ash content is quite high. In other words, for the ash content it is much more uncertain whether the average value for the ash content as derived from the samples represents the true ash content as it is present in a tray. Ash content is an important characteristic of the compost. Organic matter content in the compost is calculated as the difference between the dry matter content and the ash content. Next to this, as the ash content in the tray does not change much (trays have a closed bottom and the amount of minerals taken up from the compost into the casing soil and the mushrooms is believed to be relatively small in comparison to the absolute amount of ash present in a tray), ash content is postulated to represent some kind of internal standard when comparing compost at spawning or casing or venting with compost at the end of cultivation. It is therefore important to improve on the accuracy with which the ash content can be determined.

When analysing ash content in samples of dried and milled compost, sometimes deviant values were observed. Such samples were reanalysed by taking a second lot from the same batch of dried and milled compost (Table 7). In the second analysis, quite different values were found.

Table 7. Differences in values when deviant samples were reanalysed for ash content

\begin{tabular}{|lcc|} 
& $\begin{array}{c}\text { Ash content value in first analysis } \\
(\mathbf{g} / \mathbf{k g ~ D M})\end{array}$ & $\begin{array}{c}\text { Ash content value in second analysis } \\
\text { (g/kg DM) }\end{array}$ \\
\hline Sample 1 & 400 & 411 \\
\hline Sample 2 & 405 & 365 \\
\hline Sample 3 & 395 & 388 \\
\hline Sample 4 & 424 & 374 \\
\hline Sample 5 & 452 & 381 \\
\hline Sample 6 & 280 & 337 \\
\hline Sample 7 & 265 & 367 \\
\hline
\end{tabular}


Perhaps a method to improve on the current determination of the ash content would be to increase the amount of dried and milled compost used for the analysis.

As can be seen from Figures 2 and 4 there is quite some tray to tray variation in dry matter content and ash content. This makes it more difficult to compare trays.

\subsubsection{Increasing the accuracy with which dry matter and ash content as determined}

Any determination of the dry matter and ash content of the compost is by definition an estimation of the real dry matter and ash content. The accuracy with which values for dry matter and ash content are estimated, is improved by taking more samples from the compost. The standard error of the mean (SEM) quantifies the precision of the mean. It is a measure of how far your sample mean is likely to be from the true population mean. It is expressed in the same units as the data. The SEM is calculated by dividing the standard deviation by the square root of $\mathrm{N}$ (= number of observations). As the number of observations increases, the SEM gets smaller (i.e. the error gets smaller). As seen in Figures 3 and 5 , the SEM becomes smaller with increasing number of replicate measurements. Figure 5 suggests that at least 5 replicate samples should be taken from a tray. However, a comparison is difficult as the volumes of the samples are not the same at the different moments during cultivation. Trays contain $16 \mathrm{~kg}$ of compost. Drying all compost in a single tray would give a very accurate determination of the dry matter content of the tray. At casing and at the end of cultivation, for each tray 8 samples of about 200 gram were analysed, representing about $10 \%$ of the content of the tray. Taking three samples of 500-600 gram of compost would involve the same amount of compost in the tray. The same line of reasoning would also apply for determination of the ash content.

\subsection{Recommendations}

To lower variability in determination of dry matter and ash content, we would like to recommend to perform an experiment in which;

- At all stages of cultivation in the experiment an equal replicate samples is taken (so 8 at spawning, 8 at casing, 8 at end of cultivation)

- Influence of homogenisation of samples of fresh compost is tested (for instance, homogenisation by hand until homogeneous by eye in comparison to homogenising mechanically by using a cuttering machine which is operated at a standard speed for a standard time).

- The amount of fresh compost in a sample to be analysed for dry matter content is varied (for instance, 200, 400 and 600 gram)

- The amount of dried compost in a sample to be analysed for ash content is varied (for instance, 10, 30 and 100 gram)

- If mushrooms were grown on smaller portions of compost (for instance $8 \mathrm{~kg}$ in trays with 0.1 $\mathrm{m}^{2}$ growing surface or $4 \mathrm{~kg}$ in trays with $0.05 \mathrm{~m}^{2}$ growing surface), it will be easier to sample a large part of the compost used for cultivation. Next to this, more replicates will fit in a single growing room. 


\section{$4 \quad$ Sampling mushrooms}

Mushrooms were harvested and sorted according to mushroom quality (Class 1 small, class 1 medium, class 2 small and class 2 medium). Our standard method for determining the dry weight yield of mushrooms was sampling the mushrooms at the days of peak production and analyse them for dry weight. The average value of the dry weight determinations in the first flush was used for calculation amount of dry matter in the first flush. Likewise for calculation of the amount of dry matter in the second flush, an average value of the dry matter contents determined in the second flush was used.

In our experiment we sampled all trays in this way. For comparison, a number of trays were analysed by taking all the mushrooms that were produced and analyse them for dry matter and ash content.

\subsection{Mushroom yield and quality in the different flushes}

An overview of mushroom production by the different strains is given in Table 8. Mushrooms of the different strains were harvested according to quality class. Strain A15 produced $13785 \mathrm{~g}$ of mushrooms in two flushes on 5 trays, each filled with $16 \mathrm{~kg}$ of compost at spawning. About $49 \%$ of the mushrooms were harvested as either small or medium sized class 1 mushrooms. Strain MB-022 produced $18539 \mathrm{~g}$ of mushrooms in three flushes on 5 trays, each filled with $16 \mathrm{~kg}$ of compost at spawning. About $15 \%$ of the mushrooms were harvested as class 1 mushrooms, mainly as small mushrooms. The remaining $85 \%$ was harvested as class 2 mushrooms. The highest percentage of class 1 mushrooms was harvested in the first flush. In the second and third flush the percentage of class 1 mushrooms reduced to 13 and $6 \%$ respectively.

Table 8. Mushroom yield and quality obtained from the mushroom strains tested.

\begin{tabular}{|c|c|c|c|c|}
\hline \multirow{2}{*}{ Strain } & \multirow{2}{*}{ Flush } & \multicolumn{3}{|c|}{ Yield (gr. Fresh weight/tray) } \\
\hline & & Class 1 small & Class 1 middle & Class 2 \\
\hline A15 & & 7524 & 5496 & 13785 \\
\hline & Flush 1 & 3956 & 3833 & 6995 \\
\hline & Flush 2 & 3568 & 1663 & 6790 \\
\hline MB-022 & & 3106 & 154 & 18539 \\
\hline & Flush 1 & 1476 & 154 & 5161 \\
\hline & Flush 2 & 1514 & & 9777 \\
\hline & Flush 3 & 116 & & 3601 \\
\hline MB-031 & & 213 & & 14559 \\
\hline & Flush 1 & 213 & & 5570 \\
\hline & Flush 2 & & & 8989 \\
\hline
\end{tabular}

Strain MB-031 produced $14559 \mathrm{~g}$ of mushrooms in two flushes on 5 trays, each filled with $16 \mathrm{~kg}$ of compost at spawning. Almost all mushrooms were harvested as class 2 mushrooms. Virtually none of the mushrooms could be harvested as class 1 mushrooms.

\subsection{Dry matter content of mushrooms}

Dry matter content was measured for all quality classes of mushrooms. Differences in dry matter content were tested statistically in an unbalanced ANOVA. Significant differences were found in dry matter content of the mushroom between the different mushroom strains grown (Table 9). 
Table 9. Differences in dry matter content of the various mushroom strains tested. Least significant difference (at $p=5 \%$ ) is 1.8 .

\begin{tabular}{|c|c|c|c|c|c|}
\hline Strain & $\begin{array}{c}\text { Class } 1 \\
\text { small }\end{array}$ & $\begin{array}{l}\text { Class } 1 \\
\text { middle }\end{array}$ & Class 2 & \# observations & $\begin{array}{l}\text { Predicted value per } \\
\text { strain, based on the } \\
\text { statistical model }\end{array}$ \\
\hline A15 & 73.4 & 75.2 & 75.1 & 56 & $75.1(a)$ \\
\hline MB-022 & 83.1 & 86.2 & 83.7 & 42 & 84.4 (b) \\
\hline MB-031 & 88.7 & & 92.0 & 30 & $90.3(\mathrm{c})$ \\
\hline
\end{tabular}

As not all mushrooms produced were represented in the various quality classes differences in dry matter content of the mushrooms could not be fully analysed. Therefore no statistically significant differences in dry matter content could be demonstrated between the different quality classes.

\subsection{Comparison of methods used to calculate amount of dry matter that is produced.}

As mentioned above, two different methods were used to estimate the total amount of dry matter that is produced on the trays. In our standard method, fresh weight of harvested mushrooms is recorded on a daily basis. For estimation of the amount of dry weight that is produced, harvested mushrooms are sampled at the days of peak production and analysed for dry weight. The average value of the dry weight determinations in the first flush was used for calculation amount of dry matter in the first flush. Likewise for calculation of the amount of dry matter in the second flush, an average value of the dry matter contents determined in the second flush was used.

As an alternative, for 3 out of 5 trays we dried all mushrooms that were produced and recorded the amounts of dry weight. Table 10 shows a comparison of both methods to estimate the total amounts of dry matter produced. Statistical analysis using ANOVA shows statistically significant differences $(p=5 \%)$ between the mushroom strains in the total amounts of dry matter produced. No significant differences were found between the two methods used to estimate the total amount of dry matter produced as mushrooms. Also at the level of the different flushes, the differences between the two methods used are minor.

As a result, we adopt the method of calculating the total amount of dry matter produced as mushrooms based on the dry weight of a random sample of fresh mushrooms (about $200 \mathrm{gram}$ ).

Table 10. Overview of the amounts of dry matter produced, if determined by two different methods.

\begin{tabular}{|c|c|c|c|c|}
\hline \multirow[b]{2}{*}{ Strain } & \multirow[b]{2}{*}{ Tray } & \multirow[b]{2}{*}{ Flush } & \multicolumn{2}{|c|}{ Total amount of dry matter produced } \\
\hline & & & $\begin{array}{l}\text { Based on dry matter content } \\
\text { determined on the peak day of } \\
\text { production in a flush }\end{array}$ & $\begin{array}{c}\text { Based on the actual total } \\
\text { amount of dry matter }\end{array}$ \\
\hline \multirow{10}{*}{ A15 } & & & 1122 & 1142 \\
\hline & Tray 4 & & 347 & 362 \\
\hline & & Flush 1 & 180 & 189 \\
\hline & & Flush 2 & 167 & 173 \\
\hline & Tray 5 & & 395 & 384 \\
\hline & & Flush 1 & 212 & 203 \\
\hline & & Flush 2 & 184 & 181 \\
\hline & Tray 7 & & 380 & 395 \\
\hline & & Flush 1 & 200 & 209 \\
\hline & & Flush 2 & 180 & 186 \\
\hline
\end{tabular}


Table 10 (cont'd). Overview of the amounts of dry matter produced, if determined by two different methods.

\begin{tabular}{|c|c|c|c|c|}
\hline \multirow[b]{2}{*}{ Strain } & \multirow[b]{2}{*}{ Tray } & \multirow[b]{2}{*}{ Flush } & \multicolumn{2}{|c|}{ Total amount of dry matter produced } \\
\hline & & & $\begin{array}{c}\text { Based on dry matter content } \\
\text { determined on the peak day of } \\
\text { production in a flush }\end{array}$ & $\begin{array}{c}\text { Based on the actual total } \\
\text { amount of dry matter }\end{array}$ \\
\hline \multirow{13}{*}{ MB-022 } & & & 1066 & 1072 \\
\hline & Tray 3 & & 416 & 419 \\
\hline & & Flush 1 & 107 & 101 \\
\hline & & Flush 2 & 234 & 242 \\
\hline & & Flush 3 & 76 & 75 \\
\hline & Tray 9 & & 310 & 313 \\
\hline & & Flush 1 & 93 & 100 \\
\hline & & Flush 2 & 169 & 164 \\
\hline & & Flush 3 & 48 & 49 \\
\hline & Tray 10 & & 340 & 340 \\
\hline & & Flush 1 & 97 & 94 \\
\hline & & Flush 2 & 175 & 178 \\
\hline & & Flush 3 & 68 & 68 \\
\hline \multirow{10}{*}{ MB-031 } & & & 751 & 755 \\
\hline & Tray 10 & & 213 & 214 \\
\hline & & Flush 1 & 25 & 25 \\
\hline & & Flush 2 & 188 & 190 \\
\hline & Tray 2 & & 259 & 262 \\
\hline & & Flush 1 & 107 & 106 \\
\hline & & Flush 2 & 152 & 155 \\
\hline & Tray 6 & & 279 & 279 \\
\hline & & Flush 1 & 145 & 144 \\
\hline & & Flush 2 & 134 & 136 \\
\hline
\end{tabular}




\section{$5 \quad$ Mass balances}

\subsection{From spawning to casing}

Table 11 gives an overview of the amounts of dry matter in each tray at spawning and at casing. Data were calculated on basis of the amount of fresh weight compost in each tray and the dry matter content listed in Table 2. In general there is a decrease in the amount of dry matter during this period. However there is a considerable variation from tray to tray. Testing by ANOVA showed that the

Table 11. Amounts of dry matter per tray of compost for the different strains tested at spawning and at casing.

\begin{tabular}{|c|c|c|c|c|c|}
\hline \multirow[t]{2}{*}{ Strain } & \multirow[t]{2}{*}{ Tray } & \multicolumn{2}{|c|}{$\begin{array}{c}\text { Amount of compost dry matter } \\
\text { per tray }(\mathrm{kg})\end{array}$} & \multirow[t]{2}{*}{ Decrease $(\mathbf{k g})$} & \multirow{2}{*}{$\begin{array}{c}\text { Average } \\
\text { decrease }(\mathbf{k g})\end{array}$} \\
\hline & & At spawning & At casing & & \\
\hline \multirow{5}{*}{ A15 } & 4 & 5.437 & 5.230 & 0.208 & \multirow{5}{*}{0.133} \\
\hline & 5 & 5.437 & 5.275 & 0.162 & \\
\hline & 7 & 5.437 & 5.281 & 0.156 & \\
\hline & 8 & 5.437 & 5.406 & 0.032 & \\
\hline & 15 & 5.437 & 5.332 & 0.105 & \\
\hline \multirow{5}{*}{ MB-022 } & 3 & 5.437 & 5.324 & 0.113 & \multirow{5}{*}{0.129} \\
\hline & 9 & 5.437 & 5.403 & 0.035 & \\
\hline & 10 & 5.437 & 5.256 & 0.182 & \\
\hline & 11 & 5.437 & 5.327 & 0.110 & \\
\hline & 14 & 5.437 & 5.235 & 0.202 & \\
\hline \multirow{5}{*}{ MB-031 } & 1 & 5.437 & 5.401 & 0.036 & \multirow{5}{*}{0.099} \\
\hline & 2 & 5.437 & 5.323 & 0.114 & \\
\hline & 6 & 5.437 & 5.300 & 0.137 & \\
\hline & 12 & 5.437 & 5.395 & 0.043 & \\
\hline & 13 & 5.437 & 5.273 & 0.164 & \\
\hline
\end{tabular}

Table 12. Amounts of ash per tray of compost for the different strains tested at spawning and casing.

\begin{tabular}{|c|c|c|c|c|c|}
\hline \multirow{2}{*}{ Strain } & \multirow{2}{*}{ Tray } & \multicolumn{2}{|c|}{ Amount of ash per tray (kg) } & \multirow[t]{2}{*}{ Decrease $(\mathbf{k g})$} & \multirow{2}{*}{$\begin{array}{c}\text { Average } \\
\text { decrease }(\mathbf{k g})\end{array}$} \\
\hline & & At spawning & At casing & & \\
\hline \multirow{5}{*}{ A15 } & 4 & 2.043 & 1.874 & 0.168 & \multirow{5}{*}{0.198} \\
\hline & 5 & 2.043 & 1.803 & 0.240 & \\
\hline & 7 & 2.043 & 1.815 & 0.228 & \\
\hline & 8 & 2.043 & 1.953 & 0.090 & \\
\hline & 15 & 2.043 & 1.777 & 0.266 & \\
\hline \multirow{5}{*}{ MB-022 } & 3 & 2.043 & 1.885 & 0.158 & \multirow{5}{*}{0.164} \\
\hline & 9 & 2.043 & 2.055 & -0.013 & \\
\hline & 10 & 2.043 & 1.815 & 0.228 & \\
\hline & 11 & 2.043 & 1.882 & 0.161 & \\
\hline & 14 & 2.043 & 1.756 & 0.287 & \\
\hline \multirow{5}{*}{ MB-031 } & 1 & 2.043 & 1.944 & 0.099 & \multirow{5}{*}{0.197} \\
\hline & 2 & 2.043 & 1.863 & 0.180 & \\
\hline & 6 & 2.043 & 1.831 & 0.212 & \\
\hline & 12 & 2.043 & 1.874 & 0.169 & \\
\hline & 13 & 2.043 & 1.715 & 0.328 & \\
\hline
\end{tabular}


Table 13. . Amounts of dry matter per tray of compost for the different strains tested at spawning and at the end of cultivation.

\begin{tabular}{|c|c|c|c|c|c|}
\hline \multirow[t]{2}{*}{ Strain } & \multirow[t]{2}{*}{ Tray } & \multicolumn{2}{|c|}{$\begin{array}{c}\text { Amount of compost dry matter } \\
\text { per tray (kg) }\end{array}$} & \multirow[t]{2}{*}{ Decrease (kg) } & \multirow{2}{*}{$\begin{array}{c}\text { Average } \\
\text { decrease (kg) }\end{array}$} \\
\hline & & At spawning & End of cultivation & & \\
\hline \multirow{5}{*}{ A15 } & 4 & 5.437 & 4.396 & 1.042 & \multirow{5}{*}{1.080} \\
\hline & 5 & 5.437 & 4.351 & 1.086 & \\
\hline & 7 & 5.437 & 4.345 & 1.092 & \\
\hline & 8 & 5.437 & 4.373 & 1.065 & \\
\hline & 15 & 5.437 & 4.324 & 1.113 & \\
\hline \multirow{5}{*}{ MB-022 } & 3 & 5.437 & 4.319 & 1.119 & \multirow{5}{*}{1.078} \\
\hline & 9 & 5.437 & 4.382 & 1.056 & \\
\hline & 10 & 5.437 & 4.405 & 1.032 & \\
\hline & 11 & 5.437 & 4.326 & 1.111 & \\
\hline & 14 & 5.437 & 4.365 & 1.072 & \\
\hline \multirow{5}{*}{ MB-031 } & 1 & 5.437 & 4.527 & 0.910 & \multirow{5}{*}{0.944} \\
\hline & 2 & 5.437 & 4.468 & 0.970 & \\
\hline & 6 & 5.437 & 4.522 & 0.915 & \\
\hline & 12 & 5.437 & 4.489 & 0.949 & \\
\hline & 13 & 5.437 & 4.461 & 0.977 & \\
\hline
\end{tabular}

differences were not statistically valid at $p=5 \%$. Table 12 gives an overview of the amounts of ash in each tray at spawning and at casing. Data were calculated on basis of the amount of dry matter as listed in Table 11 and the ash content of the dry matter listed in Table 3. In contrast to the expectation, there appears to be a decrease in the amount of ash during this period. As the experiment was performed in trays with a closed bottom (so no water with solids dripping out) and casing soil was not yet applied (so no transport of salts to the casing soil) and bearing in mind the inaccuracy in determining the ash content of the compost, this is probably an artefact.

\subsection{From spawning till the end of cultivation}

Table 13 gives an overview of the amounts of dry matter in each tray at spawning and at the end of cultivation. Data were calculated on basis of the amount of fresh weight compost in each tray and the dry matter content listed in Table 5 . There is a considerable decrease in the amount of dry matter during this period, which varies from tray to tray. On average the decrease in dry weight of the compost is more or less the same for strains A15 and MB-022. The decrease in dry weight of the compost is smaller for strain MB-031. Testing by ANOVA showed that strain MB-031 statistically significant $(p=5 \%)$ reduced the amount of dry matter in the compost less than strains A15 and MB022.

Table 14 gives an overview of the amounts of ash in each tray at spawning and at the end of cultivation. Data were calculated on basis of the amount of dry matter as listed in Table 11 and the ash content of the dry matter listed in Table 6. On average, there appears to be a decrease in the amount of ash during this period. This appears reasonable as minerals are assumed to be transported to the mushrooms. Next to this the amount of salt in the casing soil increases, possibly by transport of salts from the compost to the casing soil). However, there is a lot of tray to tray variability. For instance trays 1 and 4 appear to have gained small amounts of ash, tray 12 appears to have the same amount of ash at the end of cultivation as it had at spawning and all the other trays seem to have lost a variety of amounts of ash during the period of spawn-run and cropping. However, the decrease in amount of ash per tray seems not to be as large as it was for the comparison of the amount of ash per tray at spawning and at casing.

We assume these figures to be artefacts and expect that a more reliable sampling method of the compost will limit the tray to tray variation in amounts of ash that remain after cultivation. 
Table 14. Amounts of ash per tray of compost for the different strains tested at spawning and at the end of cultivation.

\begin{tabular}{|c|c|c|c|c|c|}
\hline \multirow[t]{2}{*}{ Strain } & \multirow[t]{2}{*}{ Tray } & \multicolumn{2}{|c|}{$\begin{array}{c}\text { Amount of compost dry matter } \\
\text { per tray }(\mathrm{kg})\end{array}$} & \multirow[t]{2}{*}{ Decrease $(\mathbf{k g})$} & \multirow{2}{*}{$\begin{array}{l}\text { Average } \\
\text { decrease }\end{array}$} \\
\hline & & At spawning & End of cultivation & & \\
\hline \multirow{5}{*}{ A15 } & 4 & 2.043 & 2.055 & -0.013 & \multirow{5}{*}{0.086} \\
\hline & 5 & 2.043 & 1.916 & 0.126 & \\
\hline & 7 & 2.043 & 1.933 & 0.110 & \\
\hline & 8 & 2.043 & 1.913 & 0.130 & \\
\hline & 15 & 2.043 & 1.967 & 0.076 & \\
\hline \multirow{5}{*}{ MB-022 } & 3 & 2.043 & 1.986 & 0.056 & \multirow{5}{*}{0.059} \\
\hline & 9 & 2.043 & 1.987 & 0.056 & \\
\hline & 10 & 2.043 & 2.001 & 0.042 & \\
\hline & 11 & 2.043 & 2.001 & 0.042 & \\
\hline & 14 & 2.043 & 1.943 & 0.099 & \\
\hline \multirow{5}{*}{ MB-031 } & 1 & 2.043 & 2.086 & -0.044 & \multirow{5}{*}{0.029} \\
\hline & 2 & 2.043 & 1.978 & 0.065 & \\
\hline & 6 & 2.043 & 1.961 & 0.081 & \\
\hline & 12 & 2.043 & 2.044 & -0.001 & \\
\hline & 13 & 2.043 & 2.001 & 0.042 & \\
\hline
\end{tabular}

\subsection{Biological efficiency}

Calculation of the biological efficiency combines the decrease in dry matter in the compost with the production of dry matter in the mushrooms. Not all dry matter that disappears from the compost contributes to the production of mushrooms. Dry matter in the compost is decomposed and transformed into biomass, $\mathrm{CO}_{2}$ and $\mathrm{H}_{2} \mathrm{O}$. The biomass that is formed is present in the compost in the form of mycelium. Next to this it is present in the mycelium that is present in the casing soil. It is also present in the mushrooms that are produced.

However, upon harvest the lower parts of the stipes (the stumps) are removed from the mushroom. As a rule of thumb, about $15 \%$ of the total fresh weight of the mushroom is removed with the lower part of the stipe. We calculate the biological efficiency as the quotient of the amount of

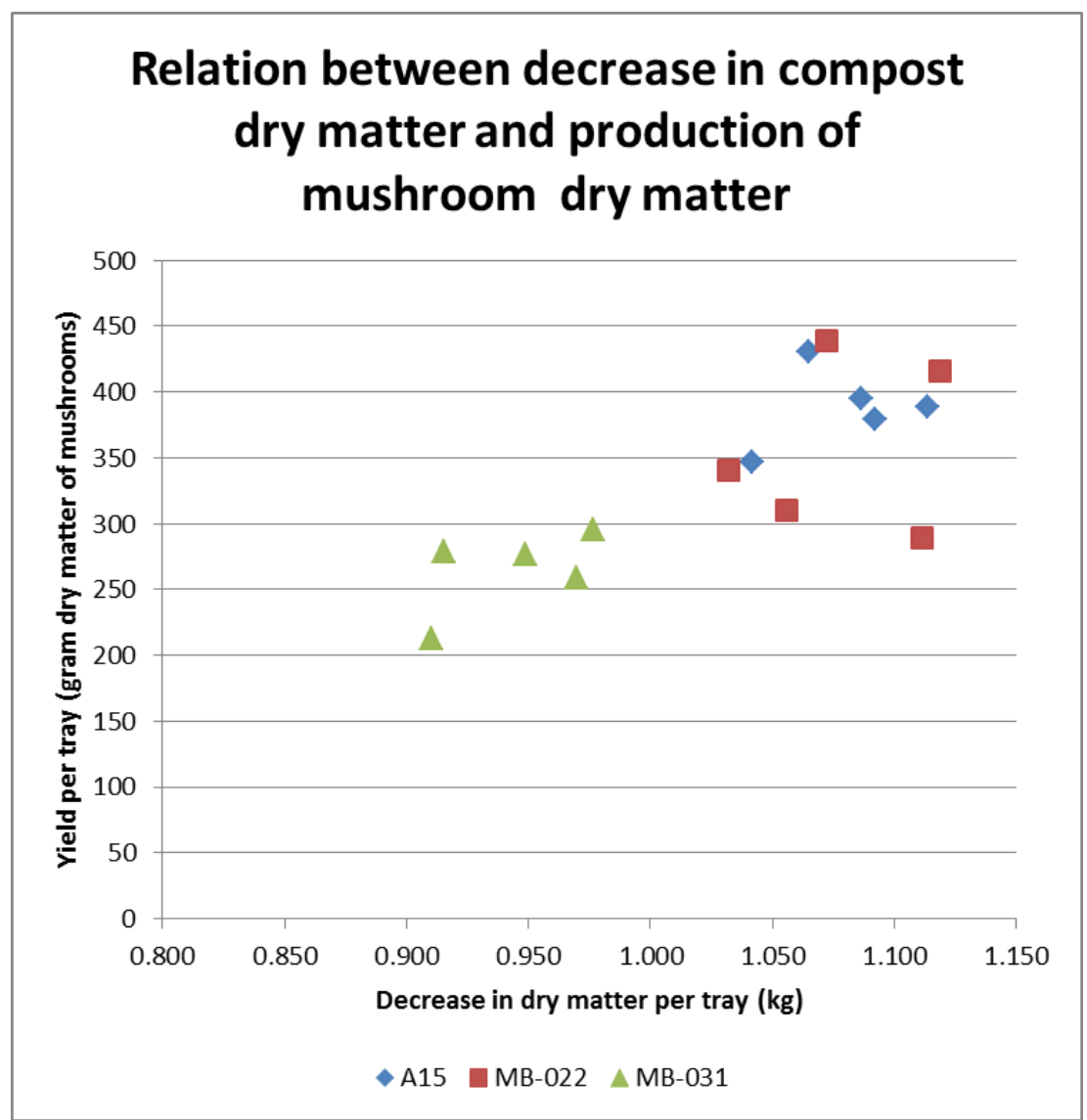

Figure 6. Relationship between the decrease of dry matter per tray and the dry matter present in the mushrooms (stumps excluded). 
dry matter present in the mushrooms (stumps excluded) and the loss of dry matter in the compost. In reality, the compost that has been degraded is larger than the loss in dry matter suggests. Part of the dry matter that is degraded is transformed into mycelium that is present in the compost. Figure 6 displays the relationship between the amount of dry matter that has disappeared from the compost and the amount of dry matter in the harvested mushrooms. Raw data used to draw the graph in Figure 6 are listed in Table 15. As can be seen, while the data points for strains A15 and MB-031 more or less form a straight line, especially strain MB-022 shows a lot of variation.

For comparison of the yield in this experiment to yield in commercial practice; strain A15 produced in 2 flushes on average $351 \mathrm{~kg} /$ ton compost, strain MB-022 produced on average $286 \mathrm{~kg} /$ ton compost and strain MB-031 produced on average $194 \mathrm{~kg} /$ ton compost. These calculations are based on the fresh weight of compost as determined at casing (more or less comparable to phase 3 compost).

Table 15. Biological efficiency as calculated for the different trays in the experiment.

\begin{tabular}{|lcccccc|}
\hline Strain & Tray & $\begin{array}{c}\text { At } \\
\text { spawning }\end{array}$ & $\begin{array}{c}\text { End of } \\
\text { cultivation }\end{array}$ & $\begin{array}{c}\text { Decrease } \\
(\mathrm{kg})\end{array}$ & $\begin{array}{c}\text { Mushroom Yield } \\
(\mathrm{g} \text {. dry matter) }\end{array}$ & Biol eff $(\%)$ \\
\hline A15 & 4 & 5.437 & 4.396 & 1.042 & 347 & $33.3 \%$ \\
\hline A15 & 5 & 5.437 & 4.351 & 1.086 & 395 & $36.4 \%$ \\
\hline A15 & 8 & 5.437 & 4.345 & 1.092 & 380 & $34.8 \%$ \\
\hline A15 & 15 & 5.437 & 4.373 & 1.065 & 331 & $34.5 \%$ \\
\hline MB-022 & 3 & 5.437 & 4.324 & 1.113 & 416 & $37.2 \%$ \\
\hline MB-022 & 9 & 5.437 & 4.382 & 1.056 & 310 & $29.4 \%$ \\
\hline MB-022 & 10 & 5.437 & 4.405 & 1.032 & 289 & $33.0 \%$ \\
\hline MB-022 & 11 & 5.437 & 4.326 & 1.111 & 438 & $26.0 \%$ \\
\hline MB-022 & 14 & 5.437 & 4.365 & 1.072 & 213 & $40.9 \%$ \\
\hline MB-031 & 1 & 5.437 & 4.527 & 0.910 & 259 & $23.4 \%$ \\
\hline MB-031 & 2 & 5.437 & 4.468 & 0.970 & 279 & $26.7 \%$ \\
\hline MB-031 & 6 & 5.437 & 4.522 & 0.915 & 277 & $30.5 \%$ \\
\hline MB-031 & 12 & 5.437 & 4.489 & 0.949 & 295 & $29.2 \%$ \\
\hline MB-031 & 13 & 5.437 & 4.461 & 0.977 & $30.2 \%$ \\
\hline
\end{tabular}

Biological efficiency for strain A15 ranged from 33 to 40\%; on average 36\%. In a previous experiment a biological efficiency of $29.3 \%$ was found (for 2 flushes harvested, Baars \& Sonnenberg, 2014). For strain MB-022 biological efficiency ranged from 26 to 40\%; on average 33\%. In a previous experiment a biological efficiency of $30.6 \%$ was found (for 2 flushes harvest, Baars \& Sonnenberg, 2014).

For strain MB-031 biological efficiency ranged from 23 to $31 \%$; on average $28 \%$. In a previous experiment a biological efficiency of $19.4 \%$ was found (for 2 flushes harvest, Baars \& Sonnenberg, 2014).

The data on biological efficiency in Table 15 were analysed by ANOVA. Statistically significant differences in biological efficiency were seen (Table 16). The least significant difference was found to be $5.7 \%$. From this it can be concluded that with the current methods of analysing dry matter and ash content of compost, it will not be possible to discriminate reliably between mushroom strains that differ less than $5.7 \%$ from each other with respect to biological efficiency. As biological efficiency is likely to range between 0 and $40 \%$ this means that with the current method of estimating dry weight of compost we cannot discriminate accurately enough between the small differences in biological efficiency of a set of offspring, as needed for genomic mapping.

Table 16. Overview of biological efficiencies.

\begin{tabular}{|lll|}
\hline Strain & Biological efficiency & $\begin{array}{l}\text { Statistical significance (values sharing a letter are not } \\
\text { statistical significant different at } \mathbf{p = 5} \% \text { ) }\end{array}$ \\
\hline MB-031 & $\mathbf{2 8 . 0} \%$ & A \\
\hline MB-022 & $33.3 \%$ & Ab \\
\hline A15 & $36.0 \%$ & B \\
\hline
\end{tabular}




\section{Conclusions}

In the experiments described in this report, biological efficiency was determined for 3 strains of Agaricus bisporus, with the aim of accurately determining sources of variation for the terms used in the calculation of biological efficiency; amount of dry matter in the compost that is used and the amount of dry matter that is produced in the harvested mushrooms.

The largest uncertainty was found in the amount of dry matter used from the compost. The methods used for sampling the compost to determine the mean value for dry matter content demonstrated a considerable variation between replicate samples taken from the compost. To lower variability in determination of dry matter and ash content, it was recommended to;

- Take an equally high number of replicate samples from all stages of cultivation (so 8 at spawning, 8 at casing, 8 at end of cultivation)

- Test the influence of homogenisation of samples of fresh compost (for instance, homogenisation by hand until homogeneous by eye in comparison to homogenising mechanically by using a cuttering machine which is operated at a standard speed for a standard time).

- $\quad$ Test for the optimal the amount of fresh compost in a sample to be analysed for dry matter content (for instance, 200, 400 and 600 gram)

- Test for the optimal amount of dried compost to be analysed for ash content (for instance, 10, 30 and 100 gram)

- Test if cultivation of the mushrooms on smaller portions of compost (for instance $8 \mathrm{~kg}$ in trays with $0.1 \mathrm{~m}^{2}$ growing surface or $4 \mathrm{~kg}$ in trays with $0.05 \mathrm{~m}^{2}$ growing surface), makes it easier to sample a large part of the compost used for cultivation. Next to this, more replicates will fit in a single growing room.

The uncertainty in the amount of dry matter produced in mushrooms is rather small. Using the dry matter content of mushrooms sampled at the peak days of a flush of mushrooms, provided a fairly accurate prediction of the actual amount of dry mass produced. In previous experiments it has been noted however, that some strains of mushrooms do not adhere to a production pattern in flushes, they produce mushrooms more or less continuously. To obtain a fair comparison for biological efficiency it would be advisable to harvest the mushrooms until no more mushrooms are produced.

Biological efficiency was calculated for the three strains tested and the least significant difference was found to be $5.7 \%$. We hope that future experiments on improvement of the methodology used, will lower this least significant difference. 


\section{References}

Baars J \& Sonnenberg A (2014) Biologische efficiëntie substraatverbruik bij champignon - Een genetische analyse. Rapport 2014-2. 


\section{Annex 1 Values for dry matter and ash content of compost at casing.}

\begin{tabular}{|c|c|c|c|c|}
\hline Tray & Strains & Replicate sample from tray & $\begin{array}{l}\text { Dry matter content } \\
\text { (g/kg fresh weight) }\end{array}$ & $\begin{array}{c}\text { Ash content } \\
\text { (g/kg dry matter) }\end{array}$ \\
\hline 1 & MB-031 & 1 & 365 & 383 \\
\hline 1 & MB-031 & 2 & 352 & 325 \\
\hline 1 & MB-031 & 3 & 352 & 332 \\
\hline 1 & MB-031 & 4 & 353 & 360 \\
\hline 1 & MB-031 & 5 & 356 & 394 \\
\hline 1 & MB-031 & 6 & 357 & 347 \\
\hline 1 & MB-031 & 7 & 359 & 371 \\
\hline 1 & MB-031 & 8 & 363 & 368 \\
\hline 2 & MB-031 & 1 & 359 & 361 \\
\hline 2 & MB-031 & 2 & 350 & 331 \\
\hline 2 & MB-031 & 3 & 345 & 347 \\
\hline 2 & MB-031 & 4 & 356 & 378 \\
\hline 2 & MB-031 & 5 & 355 & 367 \\
\hline 2 & MB-031 & 6 & 353 & 324 \\
\hline 2 & MB-031 & 7 & 352 & 344 \\
\hline 2 & MB-031 & 8 & 354 & 347 \\
\hline 3 & MB-022 & 1 & 349 & 351 \\
\hline 3 & MB-022 & 2 & 343 & 341 \\
\hline 3 & MB-022 & 3 & 350 & 337 \\
\hline 3 & MB-022 & 4 & 354 & 350 \\
\hline 3 & MB-022 & 5 & 355 & 338 \\
\hline 3 & MB-022 & 6 & 350 & 362 \\
\hline 3 & MB-022 & 7 & 345 & 352 \\
\hline 3 & MB-022 & 8 & 353 & 400 \\
\hline 4 & A15 & 1 & 347 & 368 \\
\hline 4 & A15 & 2 & 336 & 330 \\
\hline 4 & A15 & 3 & 330 & 342 \\
\hline 4 & A15 & 4 & 341 & 351 \\
\hline 4 & A15 & 5 & 357 & 405 \\
\hline 4 & A15 & 6 & 335 & 376 \\
\hline 4 & A15 & 7 & 339 & 339 \\
\hline 4 & A15 & 8 & 342 & 355 \\
\hline 5 & A15 & 1 & 357 & 395 \\
\hline 5 & A15 & 2 & 346 & 343 \\
\hline 5 & A15 & 3 & 344 & 327 \\
\hline 5 & A15 & 4 & 352 & 335 \\
\hline 5 & A15 & 5 & 337 & 324 \\
\hline 5 & A15 & 6 & 340 & 338 \\
\hline 5 & A15 & 7 & 338 & 337 \\
\hline 5 & A15 & 8 & 345 & 335 \\
\hline
\end{tabular}




\begin{tabular}{|c|c|c|c|c|}
\hline Tray & Strains & Replicate sample from tray & $\begin{array}{l}\text { Dry matter content } \\
\text { (g/kg fresh weight) }\end{array}$ & $\begin{array}{c}\text { Ash content } \\
\text { (g/kg dry matter) }\end{array}$ \\
\hline 6 & MB-031 & 1 & 343 & 326 \\
\hline 6 & MB-031 & 2 & 355 & 364 \\
\hline 6 & MB-031 & 3 & 354 & 362 \\
\hline 6 & MB-031 & 4 & 344 & 350 \\
\hline 6 & MB-031 & 5 & 344 & 352 \\
\hline 6 & MB-031 & 6 & 345 & 337 \\
\hline 6 & MB-031 & 7 & 344 & 345 \\
\hline 6 & MB-031 & 8 & 346 & 329 \\
\hline 7 & A15 & 1 & 351 & 327 \\
\hline 7 & A15 & 2 & 349 & 346 \\
\hline 7 & A15 & 3 & 346 & 323 \\
\hline 7 & A15 & 4 & 352 & 340 \\
\hline 7 & A15 & 5 & 345 & 346 \\
\hline 7 & A15 & 6 & 348 & 340 \\
\hline 7 & A15 & 7 & 348 & 365 \\
\hline 7 & A15 & 8 & 351 & 363 \\
\hline 8 & A15 & 1 & 355 & 371 \\
\hline 8 & A15 & 2 & 356 & 351 \\
\hline 8 & A15 & 3 & 358 & 354 \\
\hline 8 & A15 & 4 & 354 & 378 \\
\hline 8 & A15 & 5 & 355 & 347 \\
\hline 8 & A15 & 6 & 358 & 352 \\
\hline 8 & A15 & 7 & 364 & 384 \\
\hline 8 & A15 & 8 & 354 & 353 \\
\hline 9 & MB-022 & 1 & 350 & 345 \\
\hline 9 & MB-022 & 2 & 353 & 347 \\
\hline 9 & MB-022 & 3 & 360 & 384 \\
\hline 9 & MB-022 & 4 & 357 & 363 \\
\hline 9 & MB-022 & 5 & 371 & 424 \\
\hline 9 & MB-022 & 6 & 351 & 364 \\
\hline 9 & MB-022 & 7 & 353 & 452 \\
\hline 9 & MB-022 & 8 & 356 & 364 \\
\hline 10 & MB-022 & 1 & 344 & 331 \\
\hline 10 & MB-022 & 2 & 350 & 361 \\
\hline 10 & MB-022 & 3 & 345 & 355 \\
\hline 10 & MB-022 & 4 & 347 & 336 \\
\hline 10 & MB-022 & 5 & 347 & 326 \\
\hline 10 & MB-022 & 6 & 347 & 343 \\
\hline 10 & MB-022 & 7 & 346 & 360 \\
\hline 10 & MB-022 & 8 & 343 & 351 \\
\hline 11 & MB-022 & 1 & 348 & 368 \\
\hline 11 & MB-022 & 2 & 347 & 353 \\
\hline 11 & MB-022 & 3 & 348 & 345 \\
\hline 11 & MB-022 & 4 & 348 & 349 \\
\hline 11 & MB-022 & 5 & 344 & 361 \\
\hline 11 & MB-022 & 6 & 345 & 350 \\
\hline 11 & MB-022 & 7 & 354 & 346 \\
\hline 11 & MB-022 & 8 & 349 & 355 \\
\hline
\end{tabular}




\begin{tabular}{|c|c|c|c|c|}
\hline Tray & Strains & Replicate sample from tray & $\begin{array}{l}\text { Dry matter content } \\
\text { (g/kg fresh weight) }\end{array}$ & $\begin{array}{c}\text { Ash content } \\
\text { (g/kg dry matter) }\end{array}$ \\
\hline 12 & MB-031 & 1 & 353 & 368 \\
\hline 12 & MB-031 & 2 & 350 & 350 \\
\hline 12 & MB-031 & 3 & 355 & 357 \\
\hline 12 & MB-031 & 4 & 357 & 359 \\
\hline 12 & MB-031 & 5 & 353 & 346 \\
\hline 12 & MB-031 & 6 & 357 & 340 \\
\hline 12 & MB-031 & 7 & 353 & 318 \\
\hline 12 & MB-031 & 8 & 352 & 341 \\
\hline 13 & MB-031 & 1 & 336 & 280 \\
\hline 13 & MB-031 & 2 & 342 & 315 \\
\hline 13 & MB-031 & 3 & 345 & 322 \\
\hline 13 & MB-031 & 4 & 342 & 316 \\
\hline 13 & MB-031 & 5 & 353 & 356 \\
\hline 13 & MB-031 & 6 & 348 & 341 \\
\hline 13 & MB-031 & 7 & 346 & 331 \\
\hline 13 & MB-031 & 8 & 349 & 339 \\
\hline 14 & MB-022 & 1 & 340 & 345 \\
\hline 14 & MB-022 & 2 & 340 & 321 \\
\hline 14 & MB-022 & 3 & 338 & 337 \\
\hline 14 & MB-022 & 4 & 340 & 336 \\
\hline 14 & MB-022 & 5 & 343 & 350 \\
\hline 14 & MB-022 & 6 & 340 & 320 \\
\hline 14 & MB-022 & 7 & 340 & 336 \\
\hline 14 & MB-022 & 8 & 345 & 338 \\
\hline 15 & A15 & 1 & 343 & 336 \\
\hline 15 & A15 & 2 & 343 & 332 \\
\hline 15 & A15 & 3 & 349 & 364 \\
\hline 15 & A15 & 4 & 343 & 350 \\
\hline 15 & A15 & 5 & 345 & 343 \\
\hline 15 & A15 & 6 & 345 & 337 \\
\hline 15 & A15 & 7 & 348 & 339 \\
\hline 15 & A15 & 8 & 348 & 265 \\
\hline
\end{tabular}




\section{Annex 2 Values for dry matter and ash content of compost at end of cultivation.}

\begin{tabular}{|c|c|c|c|c|}
\hline Tray & Strains & Replicate sample from tray & $\begin{array}{l}\text { Dry matter content } \\
\text { (g/kg fresh weight) }\end{array}$ & $\begin{array}{c}\text { Ash content } \\
\text { (g/kg dry matter) }\end{array}$ \\
\hline 1 & MB-031 & 1 & 348 & 490 \\
\hline 1 & MB-031 & 2 & 342 & 453 \\
\hline 1 & MB-031 & 3 & 338 & 461 \\
\hline 1 & MB-031 & 4 & 334 & 465 \\
\hline 1 & MB-031 & 5 & 330 & 474 \\
\hline 1 & MB-031 & 6 & 342 & 447 \\
\hline 1 & MB-031 & 7 & 339 & 441 \\
\hline 1 & MB-031 & 8 & 350 & 456 \\
\hline 2 & MB-031 & 1 & 335 & 440 \\
\hline 2 & MB-031 & 2 & 336 & 430 \\
\hline 2 & MB-031 & 3 & 334 & 442 \\
\hline 2 & MB-031 & 4 & 335 & 458 \\
\hline 2 & MB-031 & 5 & 348 & 461 \\
\hline 2 & MB-031 & 6 & 343 & 434 \\
\hline 2 & MB-031 & 7 & 341 & 448 \\
\hline 2 & MB-031 & 8 & 330 & 428 \\
\hline 3 & MB-022 & 1 & 370 & 468 \\
\hline 3 & MB-022 & 2 & 386 & 440 \\
\hline 3 & MB-022 & 3 & 373 & 473 \\
\hline 3 & MB-022 & 4 & 370 & 458 \\
\hline 3 & MB-022 & 5 & 368 & 450 \\
\hline 3 & MB-022 & 6 & 381 & 481 \\
\hline 3 & MB-022 & 7 & 378 & 457 \\
\hline 3 & MB-022 & 8 & 362 & 452 \\
\hline 4 & A15 & 1 & 364 & 440 \\
\hline 4 & A15 & 2 & 368 & 474 \\
\hline 4 & A15 & 3 & 368 & 451 \\
\hline 4 & A15 & 4 & 351 & 474 \\
\hline 4 & A15 & 5 & 363 & 475 \\
\hline 4 & A15 & 6 & 366 & 464 \\
\hline 4 & A15 & 7 & 362 & 489 \\
\hline 4 & A15 & 8 & 373 & 475 \\
\hline 5 & A15 & 1 & 362 & 437 \\
\hline 5 & A15 & 2 & 356 & 447 \\
\hline 5 & A15 & 3 & 360 & 449 \\
\hline 5 & A15 & 4 & 372 & 448 \\
\hline 5 & A15 & 5 & 354 & 432 \\
\hline 5 & A15 & 6 & 353 & 429 \\
\hline
\end{tabular}




\begin{tabular}{|c|c|c|c|c|}
\hline Tray & Strains & Replicate sample from tray & $\begin{array}{l}\text { Dry matter content } \\
\text { (g/kg fresh weight) }\end{array}$ & $\begin{array}{c}\text { Ash content } \\
\text { (g/kg dry matter) }\end{array}$ \\
\hline 5 & A15 & 7 & 345 & 433 \\
\hline 5 & A15 & 8 & 367 & 447 \\
\hline 6 & MB-031 & 1 & 328 & 428 \\
\hline 6 & MB-031 & 2 & 347 & 428 \\
\hline 6 & MB-031 & 3 & 342 & 417 \\
\hline 6 & MB-031 & 4 & 347 & 428 \\
\hline 6 & MB-031 & 5 & 361 & 442 \\
\hline 6 & MB-031 & 6 & 322 & 428 \\
\hline 6 & MB-031 & 7 & 347 & 454 \\
\hline 6 & MB-031 & 8 & 358 & 447 \\
\hline 7 & A15 & 1 & 355 & 431 \\
\hline 7 & A15 & 2 & 359 & 445 \\
\hline 7 & A15 & 3 & 359 & 427 \\
\hline 7 & A15 & 4 & 385 & 444 \\
\hline 7 & A15 & 5 & 362 & 451 \\
\hline 7 & A15 & 6 & 374 & 455 \\
\hline 7 & A15 & 7 & 380 & 456 \\
\hline 7 & A15 & 8 & 364 & 449 \\
\hline 8 & A15 & 1 & 357 & 424 \\
\hline 8 & A15 & 2 & 367 & 445 \\
\hline 8 & A15 & 3 & 366 & 436 \\
\hline 8 & A15 & 4 & 375 & 451 \\
\hline 8 & A15 & 5 & 364 & 430 \\
\hline 8 & A15 & 6 & 372 & 439 \\
\hline 8 & A15 & 7 & 360 & 432 \\
\hline 8 & A15 & 8 & 349 & 442 \\
\hline 9 & MB-022 & 1 & 358 & 451 \\
\hline 9 & MB-022 & 2 & 367 & 456 \\
\hline 9 & MB-022 & 3 & 377 & 451 \\
\hline 9 & MB-022 & 4 & 391 & 468 \\
\hline 9 & MB-022 & 5 & 380 & 443 \\
\hline 9 & MB-022 & 6 & 372 & 446 \\
\hline 9 & MB-022 & 7 & 363 & 456 \\
\hline 9 & MB-022 & 8 & 379 & 457 \\
\hline 10 & MB-022 & 1 & 372 & 450 \\
\hline 10 & MB-022 & 2 & 388 & 445 \\
\hline 10 & MB-022 & 3 & 404 & 476 \\
\hline 10 & MB-022 & 4 & 374 & 435 \\
\hline 10 & MB-022 & 5 & 390 & 473 \\
\hline 10 & MB-022 & 6 & 374 & 450 \\
\hline 10 & MB-022 & 7 & 389 & 457 \\
\hline 10 & MB-022 & 8 & 383 & 448 \\
\hline 11 & MB-022 & 1 & 358 & 470 \\
\hline 11 & MB-022 & 2 & 345 & 469 \\
\hline 11 & MB-022 & 3 & 350 & 460 \\
\hline 11 & MB-022 & 4 & 359 & 452 \\
\hline 11 & MB-022 & 5 & 359 & 462 \\
\hline
\end{tabular}




\begin{tabular}{|c|c|c|c|c|}
\hline Tray & Strains & Replicate sample from tray & $\begin{array}{l}\text { Dry matter content } \\
\text { (g/kg fresh weight) }\end{array}$ & $\begin{array}{c}\text { Ash content } \\
\text { (g/kg dry matter) }\end{array}$ \\
\hline 11 & MB-022 & 6 & 344 & 438 \\
\hline 11 & MB-022 & 7 & 351 & 483 \\
\hline 11 & MB-022 & 8 & 354 & 466 \\
\hline 12 & MB-031 & 1 & 332 & 449 \\
\hline 12 & MB-031 & 2 & 346 & 446 \\
\hline 12 & MB-031 & 3 & 349 & 451 \\
\hline 12 & MB-031 & 4 & 350 & 489 \\
\hline 12 & MB-031 & 5 & 349 & 455 \\
\hline 12 & MB-031 & 6 & 337 & 442 \\
\hline 12 & MB-031 & 7 & 346 & 443 \\
\hline 12 & MB-031 & 8 & 339 & 466 \\
\hline 13 & MB-031 & 1 & 349 & 455 \\
\hline 13 & MB-031 & 2 & 332 & 445 \\
\hline 13 & MB-031 & 3 & 348 & 462 \\
\hline 13 & MB-031 & 4 & 337 & 435 \\
\hline 13 & MB-031 & 5 & 340 & 443 \\
\hline 13 & MB-031 & 6 & 344 & 448 \\
\hline 13 & MB-031 & 7 & 346 & 448 \\
\hline 13 & MB-031 & 8 & 341 & 454 \\
\hline 14 & MB-022 & 1 & 363 & 447 \\
\hline 14 & MB-022 & 2 & 365 & 450 \\
\hline 14 & MB-022 & 3 & 371 & 446 \\
\hline 14 & MB-022 & 4 & 356 & 431 \\
\hline 14 & MB-022 & 5 & 369 & 440 \\
\hline 14 & MB-022 & 6 & 366 & 450 \\
\hline 14 & MB-022 & 7 & 360 & 461 \\
\hline 14 & MB-022 & 8 & 362 & 436 \\
\hline 15 & A15 & 1 & 346 & 443 \\
\hline 15 & A15 & 2 & 350 & 461 \\
\hline 15 & A15 & 3 & 347 & 452 \\
\hline 15 & A15 & 4 & 346 & 448 \\
\hline 15 & A15 & 5 & 364 & 464 \\
\hline 15 & A15 & 6 & 350 & 464 \\
\hline 15 & A15 & 7 & 363 & 455 \\
\hline 15 & A15 & 8 & 353 & 451 \\
\hline
\end{tabular}


Corresponding address for this report:

P.O. Box 16

6700 AA Wageningen

The Netherlands

$\mathrm{T}+31(0) 317480700$

http://www.wageningenUR.nl

PPO/PRI report 2015-5
Plant researchers of Wageningen UR aim to utilise plant properties to help solve issues concerning food, raw materials and energy. They are devoting their knowledge of plants and their up-to-date facilities to increasing the innovative capacity of our clients. In doing so, they work on improving the quality of life.

The mission of Wageningen UR (University \& Research centre) is 'To explore the potential of nature to improve the quality of life'. Within Wageningen UR, nine specialised research institutes of the DLO Foundation have joined forces with Wageningen University to help answer the most important questions in the domain of healthy food and living environment. With approximately 30 locations, 6,000 members of staff and 10,000 students, Wageningen UR is one of the leading organisations in its domain worldwide. The integral approach to problems and the cooperation between the various disciplines are at the heart of the unique Wageningen Approach. 